\section{REPRODUCTIVE ECOLOGY OF SYZYGIUM ALTERNIFOLIUM (MYRTACEAE), AN ENDEMIC AND ENDANGERED TROPICAL TREE SPECIES IN THE SOUTHERN EASTERN GHATS OF INDIA}

\section{A.J. Solomon Raju ${ }^{1}$, J. Radha Krishna ${ }^{2} \&$ P. Hareesh Chandra ${ }^{3}$}

1,2,3 Department of Environmental Sciences, Andhra University, Visakhapatnam, Andhra Pradesh 530003, India 1ajsraju@yahoo.com (corresponding author), ${ }^{2}$ jrkrishna30@gmail.com, ${ }^{3}$ hareeshchandu@gmail.com

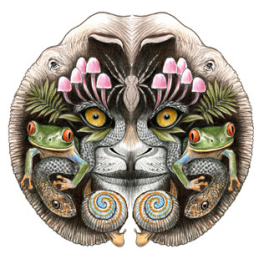

ISSN

Online 0974-7907 Print 0974-7893

OPEN ACCESS

\begin{abstract}
Syzygium alternifolium is a semi-evergreen mass-flowering tree species of dry deciduous forest in the southern Eastern Ghats of India. It is a mass bloomer with flowering during dry season. The floral traits suggest a mixed pollination syndrome involving entomophily and anemophily together called as ambophily. Further, the floral traits suggest generalist pollination system adapted for a guild of pollinating insects. The plant is self-incompatible and obligate out-crosser. The flowers are many-ovuled but only a single ovule forms seed and hence, fruit and seed set rates are the same. Natural fruit set stands at $11 \%$. Bud infestation by a moth, flower predation by the beetle, Popillia impressipyga and bud and flower mounds significantly limit fruit set rate. The ability of the plant to repopulate itself is limited by the collection of fruits by locals due to their edible nature, short viability of seeds, high seedling mortality due to water stress, nutrient deficiency and erratic rainfall or interval of drought within the rainy season. Therefore, S. alternifolium is struggling to populate itself under various intrinsic and extrinsic factors. Further studies should focus on how to assist the plant to increase its population size in its natural area taking into account the information provided in this paper.
\end{abstract}

Keywords: Ambophily, bud infestation, flower predation, generalist pollination system, self-incompatibility, seedling mortality, Syzygium alternifolium.

DOI: http://dx.doi.org/10.11609/JoTT.03768.6153-71

Editor: Raju Sekar, Xi'an Jiaotong-Liverpool University, Suzhou, China.

Date of publication: 26 August 2014 (online \& print)

Manuscript details: Ms \# 03768 | Received 15 September 2013 | Final received 28 July 2014 | Finally accepted 04 August 2014

Citation: Raju, A.J.S., J.R. Krishna \& P.H. Chandra (2014). Reproductive ecology of Syzygium alternifolium (Myrtaceae), an endemic and endangered tropical tree species in the southern Eastern Ghats of India. Journal of Threatened Taxa 6(9): 6153-6171; http://dx.doi.org/10.11609/JoTT.03768.6153-71

Copyright: (c) Raju et al. 2014. Creative Commons Attribution 4.0 International License. JoTT allows unrestricted use of this article in any medium, reproduction and distribution by providing adequate credit to the authors and the source of publication.

Funding: Ministry of Environment \& Forests, Government of India, New Delhi.

Competing Interest: The authors declare no competing interests.

Author Contribution: AJSR has conceived the concept, ideas, plan of work and did part of field work and prepared the paper. JRK and PHC did field work and tabulated the observational and experimental work of the paper.

Author Details: Prof. A.J. Solomon RAJu is Head of the Department of Environmental Sciences, Andhra University, Visakhapatnam. He is presently working on endemic and endangered plant species in southern Eastern Ghats forests with financial support from MoEF and CSIR. J. RADHA KRISHNA is working as a Junior Research Fellow in the MoEF\&CC research project registered for a PhD degree under Prof. A.J. Solomon Raju. P. HAREESH CHANDRA is working as a senior research fellow in the MoEF\&CC research project registered for a PhD degree under Prof. A.J. Solomon Raju.

Acknowledgements: This study is a part of the research work carried out under an All India Coordinated Research Project on Reproductive Biology of RET Tree species (MoEF No. 22/6/2010-RE) funded by the Ministry of Environment, Forests \& Climate Change, New Delhi sanctioned to AJSR. The second author is JRF and third author is SRF working in this project. We thank Mr. K. Venkanna, Technical Officer, Central Research Institute for Dry land Agriculture, Hyderabad, for doing soil NPK analysis.

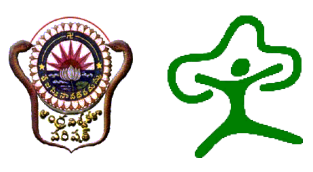




\section{INTRODUCTION}

Syzygium (Myrtaceae) is native to the tropics, particularly to tropical America and Australia. It has a worldwide, although highly uneven, distribution in tropical and subtropical regions. It is known from many countries including South Africa, South America, South East Asia and Australia. The genus comprises about 1,100 species, and has a native range that extends from Africa and Madagascar through southern Asia east through the Pacific. Its highest levels of diversity occur from Malaysia to northeastern Australia, where many species are very poorly known and many more have not been described taxonomically (Wrigley \& Fagg, 2003). In India, Syzygium has 75 species. This genus is of commercial importance with timber yielding plants such as $S$. aqueum and $S$. bracteatum and with fruit trees such as $S$. cuminii and $S$. aromaticum which are highly adapted to adverse conditions. The fruits of many plants are edible and found to be used in local medicine (Anonymous 1956). A list of 18 Syzygium species is included in the International Union for the Conservation of Nature (IUCN) Red List Plants of India (Reddy \& Reddy 2008). They are S. andamanicum, S. courtallense, S. manii, S. palghatense, S. travancoricum (Critically Endangered), S. beddomei, S. bourdillonii, S. chavaran, S. microphyllum, S. myhendrae, S. parameswaranii, S. stocksii (Endangered), S. benthamianum, S. densiflorum, S. occidentale, S. ramavarma (Vulnerable), S. utilis (Data Deficient) and S. gambleanum (Extinct). Reddy \& Reddy (2008) documented that $S$. alternifolium is an endemic and globally endangered species as per the criteria of IUCN but not yet included in the IUCN Red List.

Sanewski (2010) stated that the studied species of Syzygium for their reproductive ecology indicate that both self-compatible and self-incompatible species exist in this genus but the self-compatible species are most common. The author documented some selfcompatible species which include $S$. tierneyanum and $S$. nervosum from north Australia (Hopper 1980; Shapcott 1998), S. cuminii from India (Reddi \& Rangaiah (19992000), S. rubicundum from Sri Lanka (Stacey 2001), S. lineatum from Indonesia (Lack \& Kevan 1984), and S. samarangense, S. jambos, S. megacarpum, and S. formosum from Thailand (Chantaranothai \& Parnell 1994). In Australia, a variety of nectar feeding animals visit and pollinate $S$. tierneyanum while blossom bats and honeyeaters are primary pollinators of S. sayeri, although butterflies, flies, thrips and wasps also playing a role in pollination (Williams \& Adam 2010). S. cormiflorum is mainly pollinated by bats and followed by birds and insects (Crome \& Irvine 1986) while S. paniculatum is pollinated by honeybees, hawk moths, honeyeaters and butterflies (Payne 1991, 1997). S. floribundum is pollinated by a guild of short-tongued unspecialized insects (Williams \& Adam 2010). In American Samoa, S. inophylloides and S. samarangense are regularly foraged by birds (Cox et al. 1992). S. dealatum is both entomophilous and anemophilous (Webb \& Solek 1996). Empirical studies on the pollination of other Syzygium species in Samao are absent but observers have suggested that bats are important pollinators of these species (Wiles \& Fujita 1992; Trail 1994; Banack 1996). In Sulawesi, S. syzygiodes is pollinated by a variety of shorttongued unspecialized insects (Williams \& Adam 2010). In East Java, S. pycnanthum attracts a variety of insects but their pollination role has not been studied (Mudiana \& Ariyanti 2010). In Africa, S. guineense is reported to be a honeybee plant but details of pollination are lacking (Verdcourt 2001). In Mauritius, S. mamillatum is a rare and endemic cauliflorus species and it is pollinated by a variety of birds (Kaiser et al. 2008). In India, only S. mundagum and $S$. cuminii have been studied for their pollination biology. S. mundagum in the Western Ghats is pollinated exclusively by bats while seed dispersal takes place largely by bats (Ganesh 1996). S. cuminii is pollinated by wind, insects and gravity (Misra \& Bajpai 1984; Bajpai et al. 2012). Despite the richness of Syzygium species in India, the pollination biology of all other species has not been studied so far.

S. alternifolium occurs in the tropical dry deciduous forests of Kurnool, Cuddapah and Chittoor districts of Andhra Pradesh, Chengalpattu and North Arcot districts of Tamil Nadu and Bangalore District in Karnataka in India (Gamble 1957; Chitra 1983; Saldanha 1996; Reddy et al. 2006). Mohan \& Lakshmi (2000) reported that $S$. alternifolium occurs in the upper plateau, slopes and valley tops with dry, slaty and rocky conditions at an elevation ranging from 600-1000 $\mathrm{m}$ in Sri Venkateswara Wildlife Sanctuary of Chittoor and Cuddapah districts. They stated that the distribution of this species appears to be related to the geology and rock structure along with elevation and aspect.

S. alternifolium is a fruit tree of great timber, medicinal and economic importance. Timber is used for making furniture and agricultural implements. The plant tops are used to cure skin diseases as it has excellent anti-fungal properties (Reddy et al. 1989). The leaves are used in the treatment of liver cirrhosis, hepatitis, infective hepatitis, liver enlargement, jaundice and other ailments of liver and gall bladder. Leaves fried in cow ghee are used as a curry to treat dry cough. A 
mixture of leaves and mineral oil is used to maintain dark hair and also to promote hair growth by external application to the scalp. Tender shoots, fruits and leaf juice are used to treat dysentery, seeds for diabetes and stem bark for gastric ulcers. Flowers yield honey and possess antibiotic properties. The ripe fruits are used in making squashes and jellies. Fruit juice is used to cure stomach-ache and ulcers while the external application of fruit pulp reduces rheumatic pains (Reddy et al. 1989; Nagaraju \& Rao 1990; Rao \& Rao 2001; Bakshu 2002; Mohan et al. 2010). Despite its multiple medicinal and economic uses, the plant has not been studied for any aspect of pollination ecology. In recent years, its population size is declining due to cut down of trees and collection of fruits leaving less possibility for the plant to repopulate itself in its natural area. Keeping this in view, the present study is contemplated to describe the chronological events of pollination biology of S. alternifolium (Wight) Walp. (Myrtaceae). The observational and experimental data collected on the studied aspects are discussed in the light of relevant existing information on other Syzygium species.

\section{MATERIALS AND METHODS}

\section{Study area}

A population of about 80 individuals of S. alternifolium located in the hill and slopes of Tirumala $\left(13^{\circ} 42^{\prime \prime} \mathrm{N}\right.$ \& $79^{\circ} 20^{\prime \prime} \mathrm{E}, 858 \mathrm{~m}$ ) was used for the study during $2011-$ 2013. This area is a part of Seshachalam Hills and this region is declared in 2011 as Seshachalam Biosphere Reserve by the Ministry of Environment and Forests, Government of India. The reserve lies between $13^{\circ} 38^{\prime \prime}-$ $13^{\circ} 55^{\prime \prime} \mathrm{N} \& 79^{\circ} 07^{\prime \prime}-79^{\circ} 24^{\prime \prime} \mathrm{E}$. It is spread over $4756 \mathrm{~km}^{2}$ in both Kadapa and Chittoor districts of southern Andhra Pradesh. The vegetation is a unique mix of the dry deciduous and moist deciduous types. The elevation ranges from $150-1,130 \mathrm{~m}$ and the terrain undulating with deep forest-covered valleys and characterized by steep slopes, rocky terrain, dry and poor stony soils. The area receives most of the rainfall from northeast monsoon and little from southwest monsoon (Guptha et al. 2012).

\section{Floral biology}

Field observations on flowering intensity were made during 2011-2013. Twenty-five trees (Diameter, Breast and Height 15 \pm 4 ) were tagged for recording the phenological events for two consecutive years 2011 and 2012. Fifty tagged mature buds from 10 trees were followed for recording the time of anthesis and anther dehiscence; the mode of anther dehiscence was also noted by using a 10x hand lens. Five flowers each from ten trees selected at random were used to describe the flower details. Twenty mature but undehisced anthers from the flowers of 10 different plants were collected and placed in a petri dish. Later, each time a single anther was taken out and placed on a clean microscope slide $(75 \times 25 \mathrm{~mm})$ and dabbed with a needle in a drop of lactophenol-aniline-blue. The anther tissue was then observed under the microscope for pollen, if any, and if pollen grains were not there, the tissue was removed from the slide. The pollen mass was drawn into a band, and the total number of pollen grains was counted under a compound microscope (40x objective, 10x eye piece). This procedure was followed for counting the number of pollen grains in each anther collected. Based on these counts, the mean number of pollen produced per anther was determined. The pollen grain characteristics were recorded by consulting the book of Bhattacharya et al. (2006). Pollen dispersal rate as single grains or in aggregates was ascertained by gently touching the dehisced anthers and collecting the liberated pollen on microscope slides placed close to the anthers. The hourly pollen concentrations in the plant canopy were determined by operating rot rod samplers. Pollen spread downwind of the source, during the period of anther dehiscence was measured at a distance of $0,5,10,15,20$ and 25 meters using rotor samplers (Perkins 1957). Five flowers each from ten trees were used for testing stigma receptivity, nectar volume, sugar concentration, sugar types, protein content and amino acids. These aspects were examined following the protocols given in Dafni et al. (2005). Nectar was also analyzed for amino acid types by following the Paper Chromatography method of Baker \& Baker (1973).

\section{Foraging activity}

The foraging activity of insects was observed during day and night for 15 days in each year. In the 3-year period, the same insects were recorded. The census of foraging visits of each insect species was recorded on three different occasions in each year and the data thus collected was compiled to arrive at the average foraging visits made by each species at each hour and for the day. They were observed with reference to the type of forage they collected, contact with essential organs to result in pollination and inter-plant foraging activity in terms of cross-pollination. 


\section{Predation and breeding systems}

Bud and flower infestations were also observed in each study year and recorded their intensity to the extent possible. Fifty mature buds, five each from 10 inflorescences on five trees were bagged prior to anthesis around noon time without manual selfpollination to know whether the fruit set occurs through autogamy. Another set of 50 mature un-dehisced buds was selected in the same way and bagged. On the next day, the bags were removed, manually self-pollinated and bagged again to know whether fruit set occurs through manual self-pollination. Another set of 50 mature buds was selected again, then emasculated and bagged. The next day, the bags were removed and the stigmas were brushed with the freshly dehisced anthers from the flowers of the same tree and re-bagged to know whether fruit set occurs through geitonogamy. Another set of 50 mature buds was selected in the same way, then emasculated and bagged. The next day, the bags were removed and the stigmas were brushed with freshly dehisced anthers from the flowers of other trees and re-bagged to know whether fruit set occurs through xenogamy. Ten inflorescences on each tree were tagged for fruit set in open-pollination. The bagged flowers and tagged inflorescences were followed for eight weeks to record the results.

\section{Fruiting and seedling ecology}

Fruits and seed characteristics were also recorded. Field observations on the fruit maturation duration and dispersal mode were recorded. In vitro experiments for seed germination rate were conducted in the local forest nursery. A total of 195 seeds were sown in experimental bags and followed for result for two months. A total of 144 seeds germinated within two weeks. Further, observations were made on seed germination and seedling establishment rates in natural habitat.

\section{Soil analysis}

The soil analysis for NPK was done by the Central Research Institute for Dry land Agriculture, Hyderabad. Field observations on soil status in natural habitat were also noted.

\section{Photography}

The plant habit, flowers, fruits, seeds, seedlings, flower foragers and bud and flower infestations were photographed with a Nikon D40X Digital SLR camera (10.1 pixel).

\section{GPS coordinates}

Magellan Explorist 210 Model Digital Global Positioning System was used to record the coordinates latitude, longitude and altitude.

\section{RESULTS}

\section{Phenology}

S. alternifolium is a semi-evergreen mass-flowering tree species of dry deciduous forest (Image 1a). Leaf shedding is partial during January-March. Flower bud initiation occurs in late March while flowering occurs during mid-April to mid-May at population level (Image 1c,d). All the trees flowered massively in 2011; moderate flowering or flowering in a few branches occurred in only four trees in 2012 and 2013 and in five others only in 2012. Five others showed scattered flowering on a few branches only in 2013. Flowering was totally absent in 11 trees in 2012 and 2013. The flowering lasts 21 days (Range 16-26) in individual trees (Table 1). The flowering is almost synchronous within the population. The number of flowers opening each day is initially small, but increases rapidly, with a peak mass flowering for a fortnight and then declining rapidly. Leaf flushing begins at the end of flowering and continues into rainy season from June-August (Image 1b). The shedding of still intact old leaves takes place simultaneously.

\section{Flower morphology}

The flowers are borne in $8.62 \pm 1.26 \mathrm{~cm}$ long, terminal and axillary cymes with divaricating branches. Each inflorescence consists of 22-53 flowers. They are pedicellate, creamy-white, $16 \mathrm{~mm}$ long and $2 \mathrm{~mm}$ wide, cup-shaped $(4 \mathrm{~mm})$, actinomorphic, bisexual and sweet scented. The calyx and corolla are joined to form a cap over the bud, which falls off as a calyptra due to the pressure of the growing stamens. The stamens are

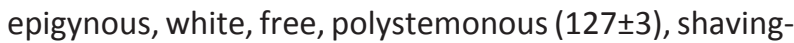
brush type and arranged on the rim of the receptacle in two whorls; the outer whorl stamens are $9 \mathrm{~mm}$ long while inner whorl stamens $6 \mathrm{~mm}$ long. The filaments are bent inwards in the bud condition but straighten at the time of anthesis. The anthers are $1 \mathrm{~mm}$ long, versatile, dithecous and introrse. The ovary is bicarpellary and bilocular syncarpous; it is $4 \mathrm{~mm}$ long and contains $21-38$ ovules on axile placentation (Image $1 \mathrm{n}$ ). The style tipped with semi-wet simple stigma is $8 \mathrm{~mm}$ long when fully grown, arises from the center of the cup and stretches out of the stamen ring by $2-3 \mathrm{~mm}$ (Image $1 / \mathrm{m}$ ). 


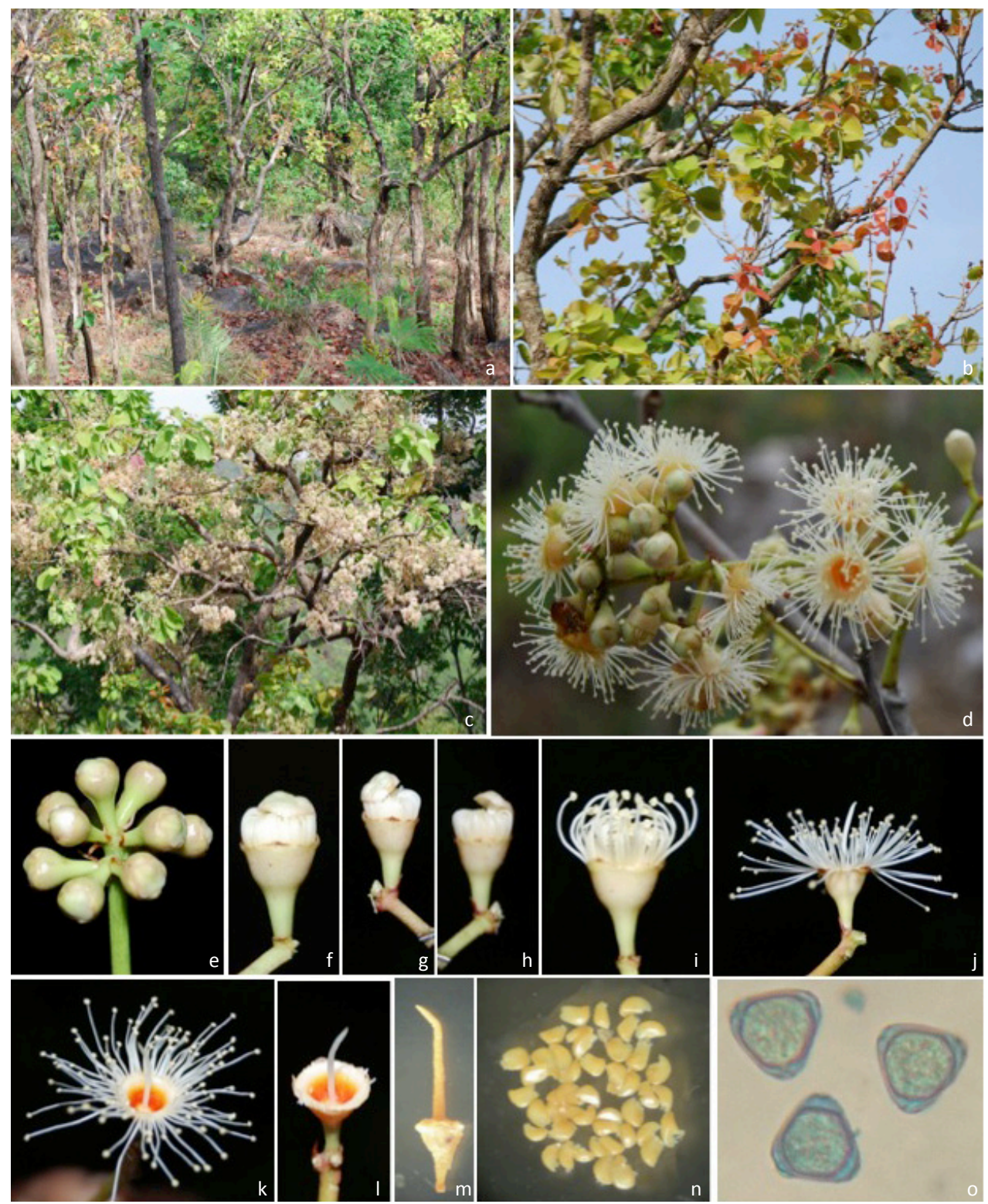

Image 1. Syzygium alternifolium: a - Habitat; b - Leaf flushing; c -Flowering phase; d -A cluster of inflorescences with buds and flowers; e - Mature buds; f-k - Different stages of anthesis; I. \& m - Calyx cup with centrally located ovary terminated with simple stigma; $n$ - Ovules; o - Pollen grains. (C) Prof. A.J. Solomon Raju.

\section{Floral biology}

The flowers open during 16:00-18:00 hr with maximum flower production at 17:00hr (Image 1 $\mathrm{e}-\mathrm{k})$. Anther dehiscence occurs following anthesis by longitudinal slits. Each anther produces $4136 \pm 192$ pollen grains and the total pollen output per flower is $5,25,272 \pm 12,408$. The pollen-ovule ratio varies from 13,833 to 25,013 . The pollen grains are creamy-white, triangular, tricolporate, triangular, $16.6 \mu \mathrm{m}$ in size, powdery and fertile (Image 10). The apertures appear as short furrows in a thickened portion of the wall. The distinctive pattern seen in polar view is formed by thinning of the exine. Most of the pollen is dislodged as single grains and it enters the ambient environment by wind. Two peak pollen concentrations were recorded, one with 17,832 pollen grains per $\mathrm{m}^{3}$ of air sampled in the evening hours between 17:00 and 20:00 hr and another with 5,721 pollen grains per $\mathrm{m}^{3}$ of air sampled in the morning hours between 07:00 and 10:00 hr. In the circadian cycle, the pollen grain concentrations varied between 17,832 and 843 for cubic meter of air sampled. The pollen concentration at peak pollen release hour

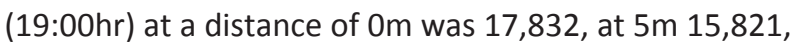

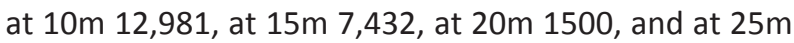


Table 1. Flowering phenology of Syzygium alternifolium

\begin{tabular}{|c|c|c|c|c|c|c|}
\hline \multirow[b]{2}{*}{ Tree No. } & \multicolumn{3}{|c|}{ Flowering season 2012} & \multicolumn{3}{|c|}{ Flowering season 2013} \\
\hline & First flowers & Last flowers & Total flowering days & First flowers & Last flowers & Total flowering days \\
\hline 1. & -- & -- & -- & -- & -- & -- \\
\hline 2. & -- & -- & -- & -- & -- & -- \\
\hline 3. & 19 April & 7 May & 20 & 19 April & 10 May & 22 \\
\hline 4. & -- & -- & -- & -- & -- & -- \\
\hline 5. & -- & -- & -- & -- & -- & -- \\
\hline 6. & 18 April & 6 May & 19 & -- & -- & -- \\
\hline 7. & -- & -- & -- & 18 April & 8 May & 21 \\
\hline 8. & 26 April & 14 May & 19 & -- & -- & -- \\
\hline 9. & -- & -- & -- & -- & -- & -- \\
\hline 10. & -- & -- & -- & -- & -- & -- \\
\hline 11. & -- & -- & -- & 14 April & 6 May & 22 \\
\hline 12. & -- & -- & -- & -- & -- & -- \\
\hline 13. & -- & -- & -- & -- & -- & -- \\
\hline 14. & 26 April & 14 May & 19 & 19 April & 14 May & 26 \\
\hline 15. & -- & -- & -- & 13 April & 7 May & 25 \\
\hline 16. & -- & -- & -- & -- & -- & -- \\
\hline 17. & 26 April & 11 May & 16 & -- & -- & -- \\
\hline 18. & -- & -- & -- & 14 April & 7 May & 23 \\
\hline 19. & 19 April & 11 May & 23 & -- & -- & -- \\
\hline 20. & 21 April & 6 May & 16 & -- & -- & -- \\
\hline 21. & -- & -- & -- & -- & -- & -- \\
\hline 22. & -- & -- & -- & -- & -- & -- \\
\hline 23. & 19 April & 11 May & 23 & 20 April & 10 May & 21 \\
\hline 24. & 17 April & 7 May & 21 & 18 April & 6 May & 19 \\
\hline 25. & -- & -- & -- & 17 April & 5 May & 19 \\
\hline
\end{tabular}

17 April - 14 May 13 April - 14 May. Flowering days: 16-23 (Mean 19 days) 19-26 (22 days)

659. The pollen concentration at second peak hour (09:00hr) was 5,721 at $0 \mathrm{~m}, 4057$ at $5 \mathrm{~m}, 3947$ at 10m, 3254 at $15 \mathrm{~m}, 2874$ at $20 \mathrm{~m}$ and 1647 at $25 \mathrm{~m}$. The stigma receptivity begins at 20:00hr and remains until the end of $2^{\text {nd }}$ day. The stamens fall at the $2^{\text {nd }}$ day of flower life while the remaining parts of the flower remain intact for five days if not pollinated. In pollinated flowers, the calyx cup is persistent and the fruit emerges out when fully grown. The nectar is secreted in the orange coloured part of the cup continuously for a period of four days from the time of anthesis. A total of $12.7 \pm 4.32$ $\mu \mathrm{l}$ of nectar is produced in the total life span of the flower. The nectar sugar concentration is $16.44 \pm 3.1 \%$; the sugars include sucrose $(2.55 \mu \mathrm{g})$, fructose $(2.37 \mu \mathrm{g})$ and glucose $(0.13 \mu \mathrm{g})$. The nectar includes six essential and nine non-essential amino acids. The essential amino acids are arginine, histidine, lysine, threonine, tryptophan and valine. The non-essential amino acids are alanine, aspartic acid, cysteine, cystine, glutamic acid, glysine, hydroxyproline, serine and tyrosine. The total protein content in the nectar is $2.55 \mu \mathrm{g}$.

\section{Flower visitors and pollination}

The flowers completely expose the anthers as well as the stigma. The flower visitors accessed the floral rewards with great ease. A total of 33 species consisting of bees, wasps, flies, beetles, butterflies (diurnal foragers), the hawk moth (crepuscular forager), and the reptilian (nocturnal forager) was recorded (Table 2). The bees included Apis dorsata (Image 2c), A. cerana (Image 2d), A. florea, Trigona iridipennis (Image 2e), Amegilla sp. (Image 2f) and Stizus sp. (Image 2g). Of these, Trigona bees foraged for nectar and also pollen, while all others for nectar only. The wasps were nectar 


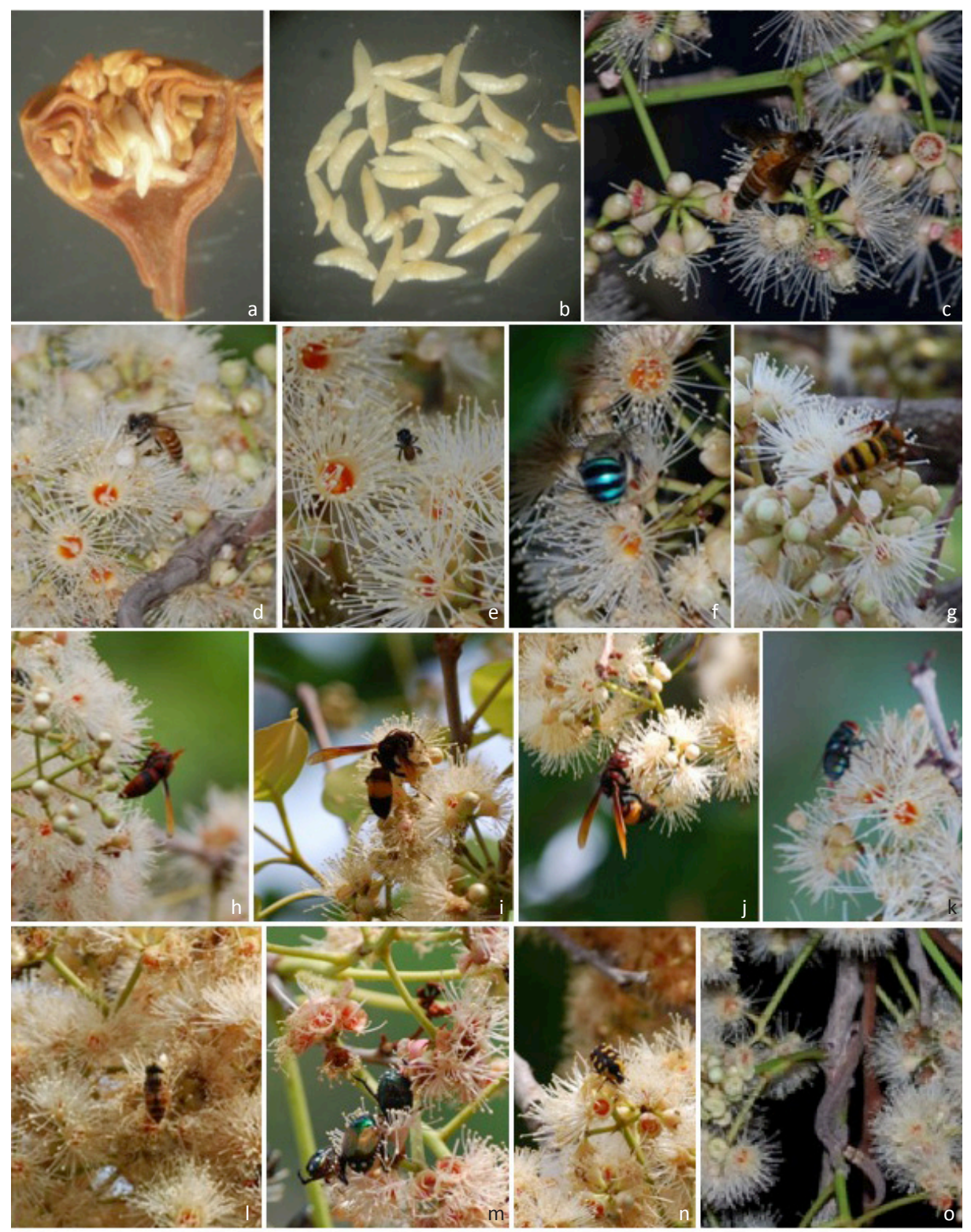

Image 2. Syzygium alternifolium: a - Bud infestation; b - Larva; c - Apis dorsata; d - Apis cerana; e - Trigona iridipennis; $\mathrm{f}$ - Amegilla sp.; g - Stizus sp.; h - Eumenes sp.; i - Vespa cincta; j - Vespa orientalis; k - Chrysomya megacephala; I - Helophilus sp.; m - Popillia impressipyga; n - Beetle (unidentified); o - Hemitheconyx caudicinctus. (C) Prof. A.J. Solomon Raju.

foragers and they were Eumenes sp. (Image $2 \mathrm{~h}$ ), Vespa cincta (Image 2i) and $V$. orientalis (Image 2j). Both the bees and wasps were regular foragers. Flies were occasional nectar foragers and they were Chrysomya megacephala (Image 2k) and Helophilus sp. (Image 2I). Beetles were Popillia impressipyga (Image $2 \mathrm{~m}$ ) and one unidentified species (Image $2 n$ ); the former was a resident forager feeding on flower parts and contributed to $26 \%$ of flower damage in 2011, 20\% in 2012 and 6\% depending on flowering intensity while the latter was an occasional nectar forager. The butterflies were regular foragers and they were Papilio polytes (Image 3a),
Graphium nomius, Catopsilia pyranthe (Image 3b), C. pomona (Image c,d), Euploea core (Image 3e), Tirumala limniace (Image 3f), Precis iphita (Image 3g), Junonia lemonias (Image 3h), Melanitis leda (Image 3i), Danaus genutia (Image 3j), Neptis hylas (Image 3k), Mycalesis perseus (Image 3I), Moduza procris, Arhopala amantes (Image 3m), Pseudocoladenia indrani (Image 4a), Borbo cinnara (Image 4b), Hasora chromus (Image 4c) and Celaenorrhinus ambareesa (Image 4d). The sphingid, Cephonodes hylas (Image 4e) was the only diurnal moth visiting the flowers regularly. The African fat-tailed gecko, Hemitheconyx caudicinctus was a resident nectar 


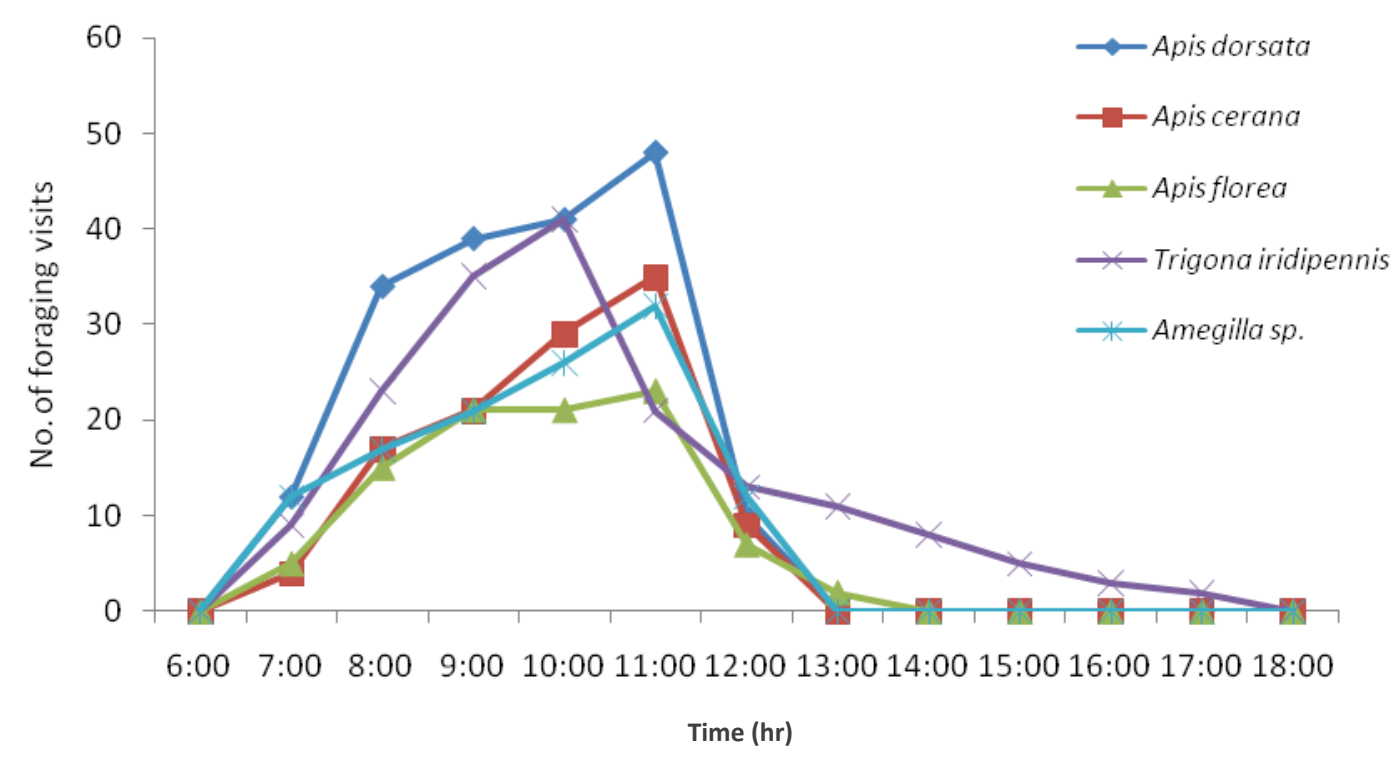

Figure 1. Hourly foraging activity of bees on Syzygium alternifolium

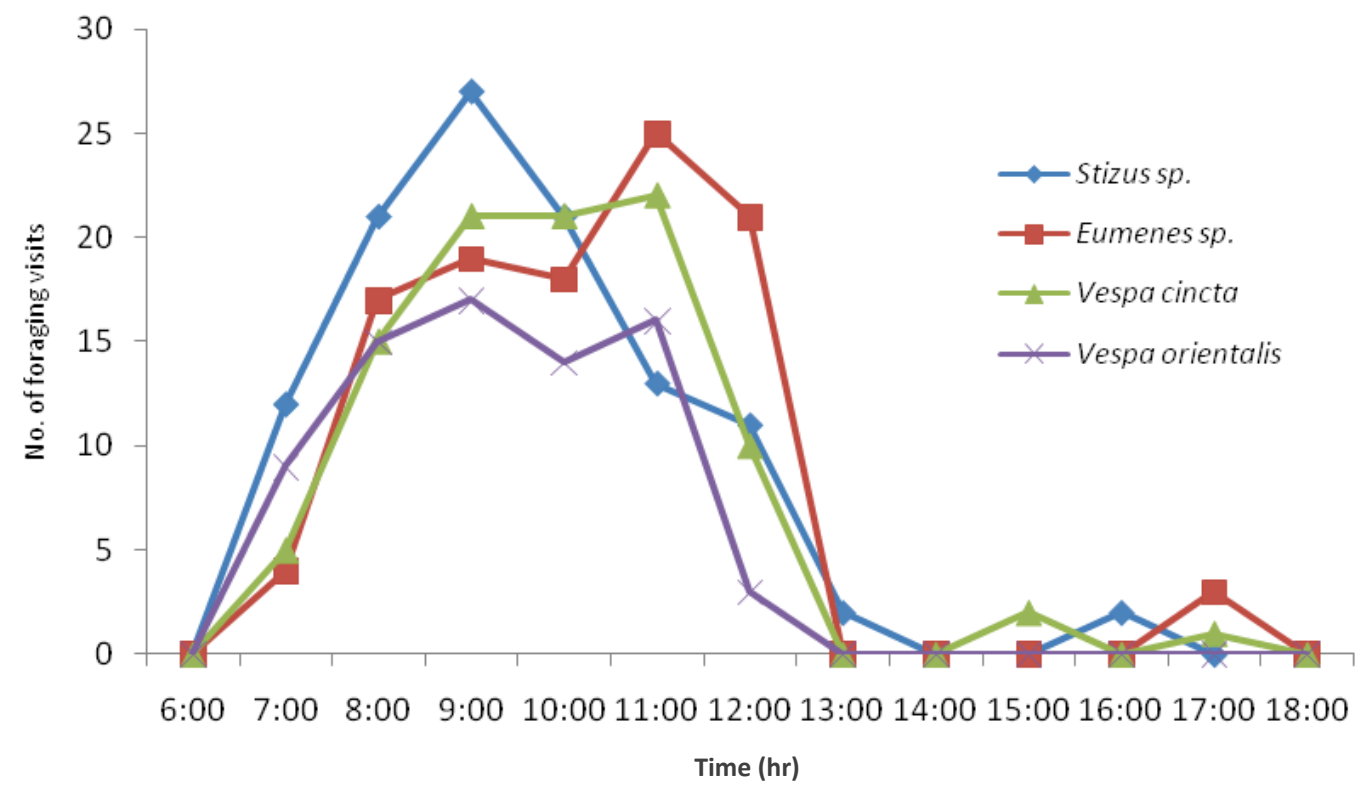

Figure 2. Hourly foraging activity of wasps on Syzygium alternifolium

forager during night time from 0600-1000 hr (Image 20).

The first visitor to just open flowers in the evening was the diurnal hawk moth, Cephonodes hylas; it continued its foraging from 16:00-19:00 hr. The same moth was the first visitor to the flowers in the morning and it foraged from 06:00-09:00 hr (Fig. 7). All other insects visited the flowers from 07:00-12:00/13:00 hr (Fig. 1-6); the flies made a few visits during 15:00-16:00 hr (Fig. 3). The intense foraging activity was recorded during 09:00-11:00 for most of the insects. Of the total foraging visits made by insects except beetles during the 3 -year period, bees constituted $25 \%$, wasps $15 \%$, flies $3 \%$, butterflies $50 \%$ and hawk moth $7 \%$ (Fig. 8). The honey bee, $A$. dorsata, wasps, butterflies and the hawk moth foraged for nectar very frequently between closely and distantly spaced conspecific trees while other bees, the unidentified beetle and the gecko tended to stay mostly on the same tree for forage collection. 

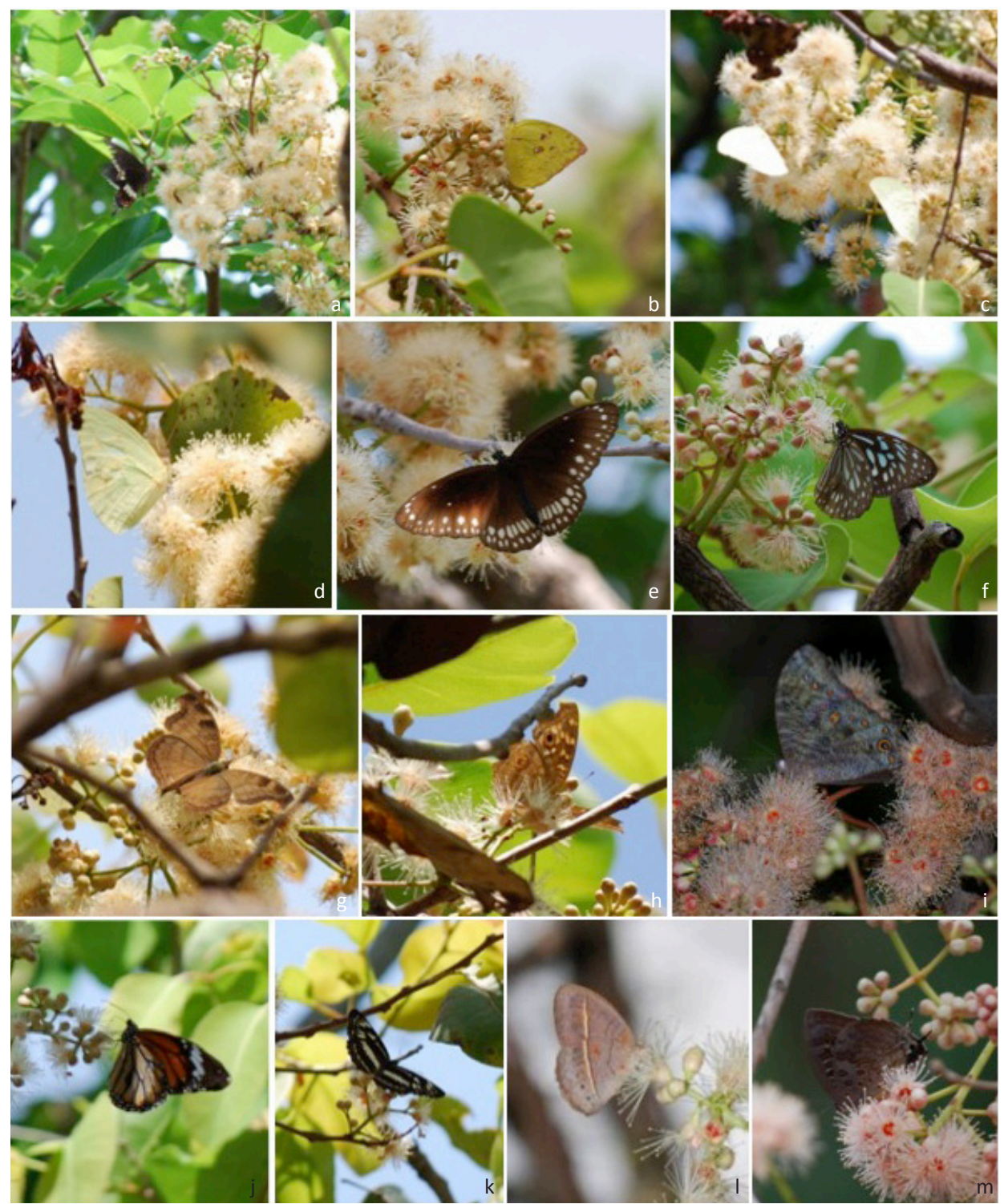

Image 3. Syzygium alternifolium: a - Papilio polytes; b - Catopsilia pyranthe; c. \& d - Catopsilia pomona; e - Euploea core; f -Tirumala limniace; g - Precis iphita; h - Junonia lemonias; i - Melanitis leda; j - Danaus genutia; k - Neptis hylas; I - Mycalesis perseus; $\mathrm{m}$ - Arhopala amantes. (C) Prof. A.J. Solomon Raju.

Table 2. Results of breeding systems in Syzygium alternifolium

\begin{tabular}{|l|c|c|c|}
\hline Pollination mode & $\begin{array}{c}\text { No. of flowers } \\
\text { bagged/tagged/ } \\
\text { pollinated }\end{array}$ & $\begin{array}{c}\text { No. of fruits } \\
\text { produced }\end{array}$ & $\begin{array}{c}\text { Fruit set } \\
\text { (\%) }\end{array}$ \\
\hline Autogamy (bagged) & 366 & 0 & 0 \\
\hline $\begin{array}{l}\text { Autogamy (manual } \\
\text { pollination, bagged) }\end{array}$ & 75 & 0 & 0 \\
\hline $\begin{array}{l}\text { Geitonogamy (manual } \\
\text { pollination, bagged) }\end{array}$ & 80 & 0 & 0 \\
\hline $\begin{array}{l}\text { Xenogamy (manual } \\
\text { pollination, bagged) }\end{array}$ & 60 & 34 & 57 \\
\hline $\begin{array}{l}\text { Open-pollination } \\
\text { (Flowers tagged prior } \\
\text { to anthesis) }\end{array}$ & 1030 & 116 & 11 \\
\hline
\end{tabular}

Flower bud as oviposition site for an unidentified moth

A moth species (unidentified) used the flower buds as oviposition site. It deposited its eggs in young flower buds and the emerged larvae consumed the entire bud over a period of approximately 3-4 days (Image 2a,b). The percentage of infested flower buds is $21 \%$ in 2011, $17 \%$ in 2012 and 4\% in 2013. Consolidated mounds formed by buds and flowers were also found and such flowers subsequently fell off (Image 4f). These infested flowers were found on all flowering branches in 2011, randomly in 2012 and rarely in 2013. These bud and flower infestations were found be to be related to the intensity of flowering in each study year. 

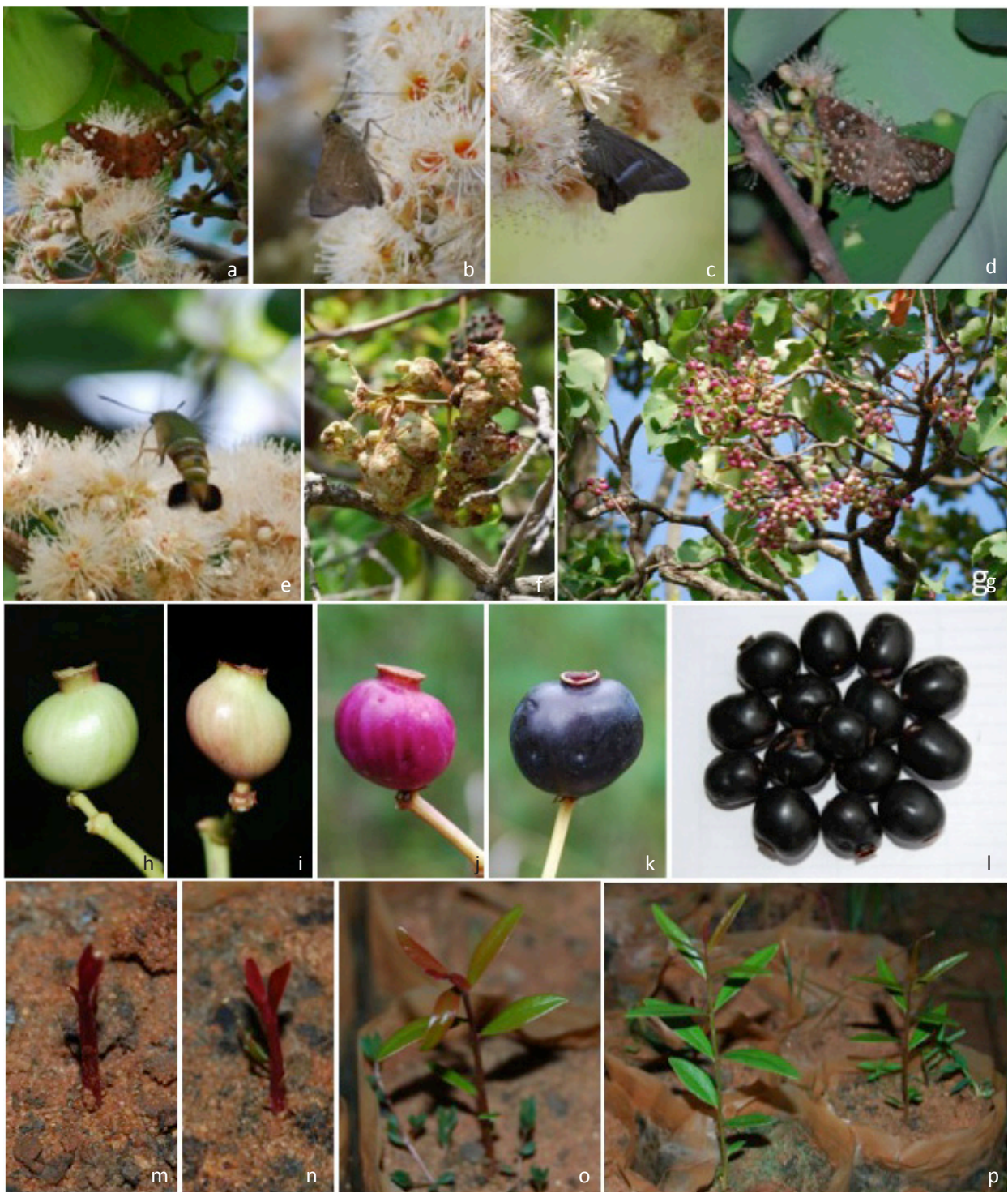

Image 4. Syzygium alternifolium: a - Pseudocoladenia indrani; b - Borbo cinnara; c - Hasora chromus; d - Celaenorrhinus ambareesa; e Cephonodes hylas; $\mathrm{f}$ - Infestation of buds and flowers; $g$ - Fruiting phase; h-k - Stages of fruit maturation; I - Ripen fruits; $m-\mathrm{p}$ - Stages of seed germination and seedling formation. (C) Prof. A.J. Solomon Raju.

\section{Breeding and fruiting behavior}

Hand-pollination experiments indicated that autogamy and geitonogamy are non-functional while xenogamy is the only mode of pollination for fruit set. In this mode, fruit set stands at $56 \%$ while in openpollination mode, it is $11 \%$ only (Table 3 ). The fertilized flowers grow, mature and ripen within two months (Image 4g-k). Fruit exhibits different colours - green, light purple, dark purple and violet during growing and maturing phase (Image 4I). It is a globose berry, luscious, fleshy, 25-30 mm in diameter and edible. It has a combination of sweet, mildly sour and astringent flavor and colours the tongue purple when eaten. The green and light purple fruits are very tasty and sweet while the dark purple and violet ones are sweet and bitter. Each fruit produces a single large seed only. The fruits fall off during late July-August. The locals were found to collect ripe fruits from trees and fallen fruits from the ground since they are edible and have commercial value.

\section{Seedling ecology}

The habitat of the plant is rocky with steep slope covered with little litter and moisture. The seedlings recorded in the area were 58 in 2011, 32 in 2012 and 17 in 2013. These were subjected to drought stress due to erratic rainfall. Further, extensive and robust grass cover during that period was found to be having impact on the surviving seedlings of the plant. Finally, 


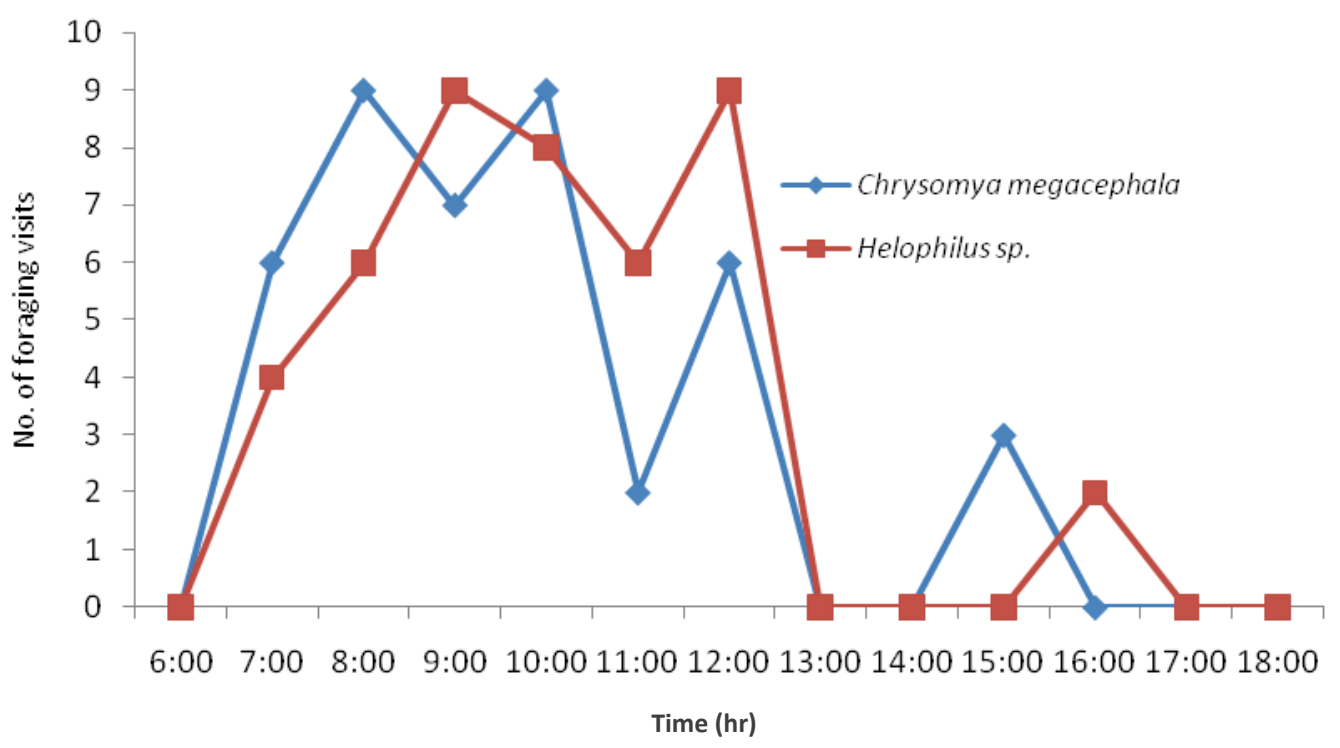

Figure 3. Hourly foraging activity of flies on Syzygium alternifolium

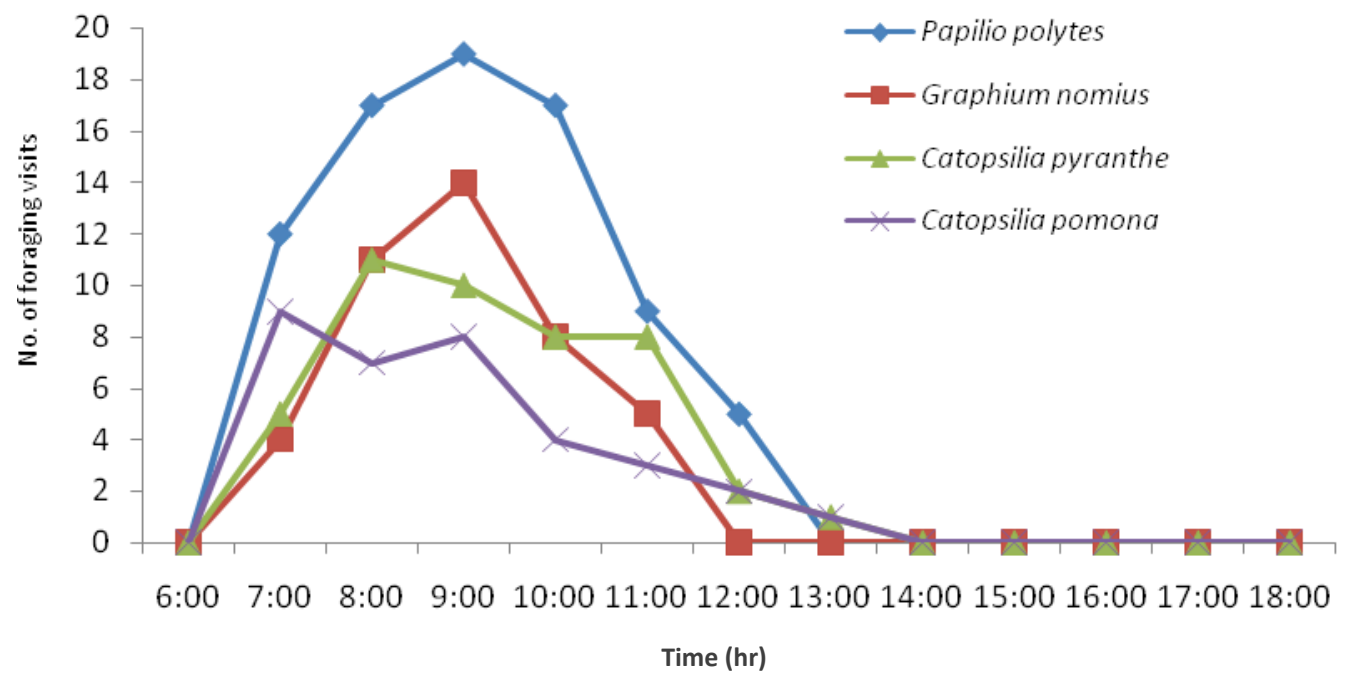

Figure 4. Hourly foraging activity of Papilionid and Pierid butterflies on Syzygium alternifolium

27 seedlings in 2011, 16 in 2012 and seven in 2013 have established and are growing continually at slow pace. The soil analysis for available nitrogen $(N)$, phosphorous (P) and potassium (K) indicated that $\mathrm{N}$ is $270 \mathrm{~kg} / \mathrm{ha}, \mathrm{P}$ $13.57 \mathrm{~kg} / \mathrm{ha}$ and $\mathrm{K} 282 \mathrm{~kg} / \mathrm{ha}$. These values show that these nutrients are not present in optimal levels and hence there is a deficiency in essential nutrients in the soil. The seeds sown in experimental bags showed that seeds germinate within two weeks and form seedlings subsequently (Image $4 m-p)$. The seed germination rate is $74 \%$.

\section{DISCUSSION}

S. alternifolium is a semi-evergreen mass-flowering tree species in the study area. It is not only endemic but also endangered due to its declining population. The plant is not found in some sites where it was reported by previous workers as cited above. It is exploited for various local uses and hence it has now attained "Endangered" status. It qualifies for inclusion in the IUCN Red List.

In Syzygium genus, the flowering pattern is of two types, mass flowering and short-period steady state flowering but most species exhibit mass flowering such 
Table 3. List of flower foragers on Syzygium alternifolium

\begin{tabular}{|c|c|c|c|c|}
\hline Order/Family & Scientific Name & Common Name & $\begin{array}{l}\text { Forage } \\
\text { collected }\end{array}$ & Visiting status \\
\hline \multicolumn{5}{|l|}{ Hymenoptera } \\
\hline \multirow[t]{5}{*}{ Apidae } & Apis dorsata $\mathrm{F}$. & Rock bee & $\mathrm{N}$ & Regular \\
\hline & A. cerana $\mathrm{F}$. & Indian honey bee & $\mathrm{N}$ & Regular \\
\hline & A. florea $\mathrm{F}$. & Dwarf honey bee & $\mathrm{N}$ & Regular \\
\hline & Trigona iridipennis Smith & Stingless bee & $N+P$ & Regular \\
\hline & Amegilla sp. & Digger bee & $\mathrm{N}$ & Regular \\
\hline Crabronidae & Stizus sp. & Sand wasp & $\mathrm{N}$ & Regular \\
\hline \multirow[t]{3}{*}{ Vespidae } & Eumenes sp. & Potter wasp & $\mathrm{N}$ & Regular \\
\hline & Vespa cincta $\mathrm{F}$. & Yellow-banded wasp & $\mathrm{N}$ & Regular \\
\hline & V. orientalis L. & Oriental Hornet & $\mathrm{N}$ & Regular \\
\hline \multicolumn{5}{|l|}{ Diptera } \\
\hline Calliphoridae & Chrysomya megacephala $\mathrm{F}$. & Oriental latrine fly & $\mathrm{N}$ & Occasional \\
\hline Syrphidae & Helophilus sp. & Hoverfly & N & Occasional \\
\hline \multicolumn{5}{|l|}{ Coleoptera } \\
\hline \multirow[t]{2}{*}{ Scarabaeidae } & Popillia impressipyga Ohaus & -- & Flower parts & Resident \\
\hline & Unidentified sp. & -- & $\mathrm{N}$ & Occasional \\
\hline \multicolumn{5}{|l|}{ Lepidoptera } \\
\hline \multirow[t]{2}{*}{ Papilionidae } & Papilio polytes $\mathrm{L}$. & Common Mormon & $\mathrm{N}$ & Regular \\
\hline & Graphium nomius Esper & Spot Swordtail & $\mathrm{N}$ & Regular \\
\hline \multirow[t]{2}{*}{ Pieridae } & Catopsilia pyranthe L. & Mottled Emigrant & $\mathrm{N}$ & Regular \\
\hline & Catopsilia pomona $\mathrm{F}$. & Common Emigrant & $\mathrm{N}$ & Regular \\
\hline \multirow[t]{9}{*}{ Nymphalidae } & Euploea core Cramer & Common Indian Crow & N & Regular \\
\hline & Tirumala limniace Cramer & Blue Tiger & $\mathrm{N}$ & Regular \\
\hline & Precis iphita Cramer & Chocolate Pansy & $\mathrm{N}$ & Regular \\
\hline & Junonia lemonias L. & Lemon Pansy & $\mathrm{N}$ & Regular \\
\hline & Melanitis leda $\mathrm{L}$. & Common Evening Brown & $\mathrm{N}$ & Regular \\
\hline & Danaus genutia Cramer & Common Tiger & $\mathrm{N}$ & Regular \\
\hline & Neptis hylas L. & Common Sailer & $\mathrm{N}$ & Regular \\
\hline & Mycalesis perseus $\mathrm{F}$. & Common Bushbrown & $\mathrm{N}$ & Regular \\
\hline & Moduza procris Cramer & The Commander & $\mathrm{N}$ & Regular \\
\hline Lycaenidae & Arhopala amantes Hewitson & Large Oakblue & $\mathrm{N}$ & Regular \\
\hline \multirow[t]{4}{*}{ Hesperiidae } & Pseudocoladenia indrani $\mathrm{F}$. & Tricolour Pied Flat & $\mathrm{N}$ & Regular \\
\hline & Borbo cinnara Wallace & Rice Swift & $\mathrm{N}$ & Regular \\
\hline & Hasora chromus Cramer & Common Banded Awl & $\mathrm{N}$ & Regular \\
\hline & Celaenorrhinus ambareesa Moore & Common Spotted Flat & $\mathrm{N}$ & Regular \\
\hline Sphingidae & Cephonodes hylas L. & Pellucid Hawk Moth & $\mathrm{N}$ & Regular \\
\hline \multicolumn{5}{|c|}{ Reptilia: Squamata } \\
\hline Gekkonidae & Hemitheconyx caudicinctus Dumeril & African fat-tailed Gecko & $\mathrm{N}$ & Resident \\
\hline
\end{tabular}

$\mathrm{N}=$ Nectar $\mathrm{P}=+$ Pollen

as S. tierneyanum (Lack \& Kevan 1984), S. cuminii (Reddi \& Rangaiah 1999-2000), S. luehmannii (Sanewski 2010), S. sayeri (Williams \& Adam 2010) and S. aqeum (Tarai $\&$ Kundu 2008). S. alternifolium is also a mass bloomer and it flowers during dry season. The flowering occurs after partial leaf shedding and leaf flushing occurs after the completion of flowering. This finding does not agree with the observation made by Mohan \& Lakshmi 


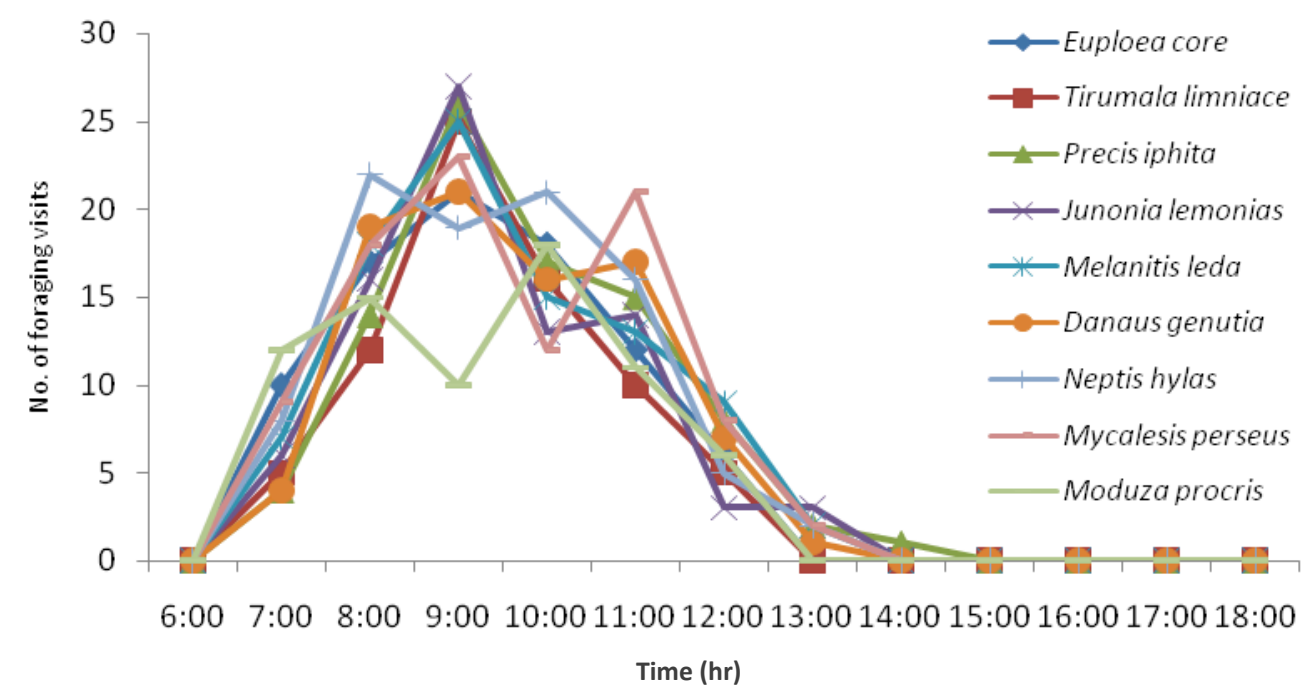

Figure 5. Hourly foraging activity of Nymphalid butterflies on Syzygium alternifolium

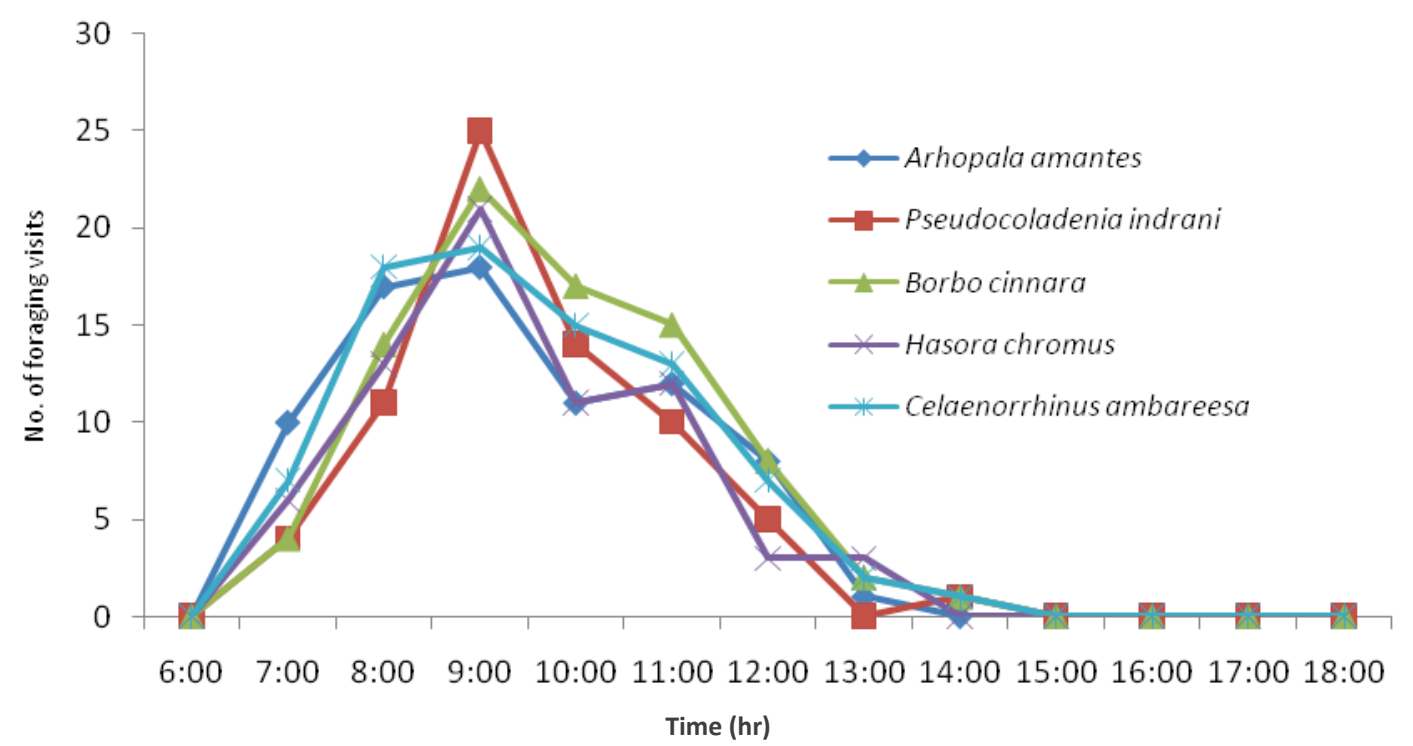

Figure 6. Hourly foraging activity of Lycaenid and Hesperiid butterflies on Syzygium alternifolium

(2000) that the flowering and fruiting events occur after new leaf formation in this species. The 3-year study on the flowering phenology of $S$. alternifolium indicated that mass flowering is not a regular event since the observations showed that flowering intensity varied, it is massive in the first year and moderate in the second and third year, and also little flowering on a few branches of some trees in the third year. Such a flowering pattern appears to be a function of abrupt changes in water availability and temperature due to erratic and low rainfall, and below optimal NPK nutrient levels in soil due to rocky terrain, dry and poor stony soils with little in situ litter accumulation. Sanewski (2010) stated that such a flowering pattern occurs in Syzygium species and the author related it to abrupt changes in water availability and temperature in monsoon sites. Troncoso et al. (2006) reported that flowering in Olea europaea is not an annual event and observed a considerable depletion of the $\mathrm{N}$ and $\mathrm{K}$ contents in the leaves at the end of the fruiting year and an increase in these values at the end of the non-flowering season. They stated that a recovery of the mineral content is required for flower bud differentiation to reoccur and water and thermal stress may induce an imbalance between 


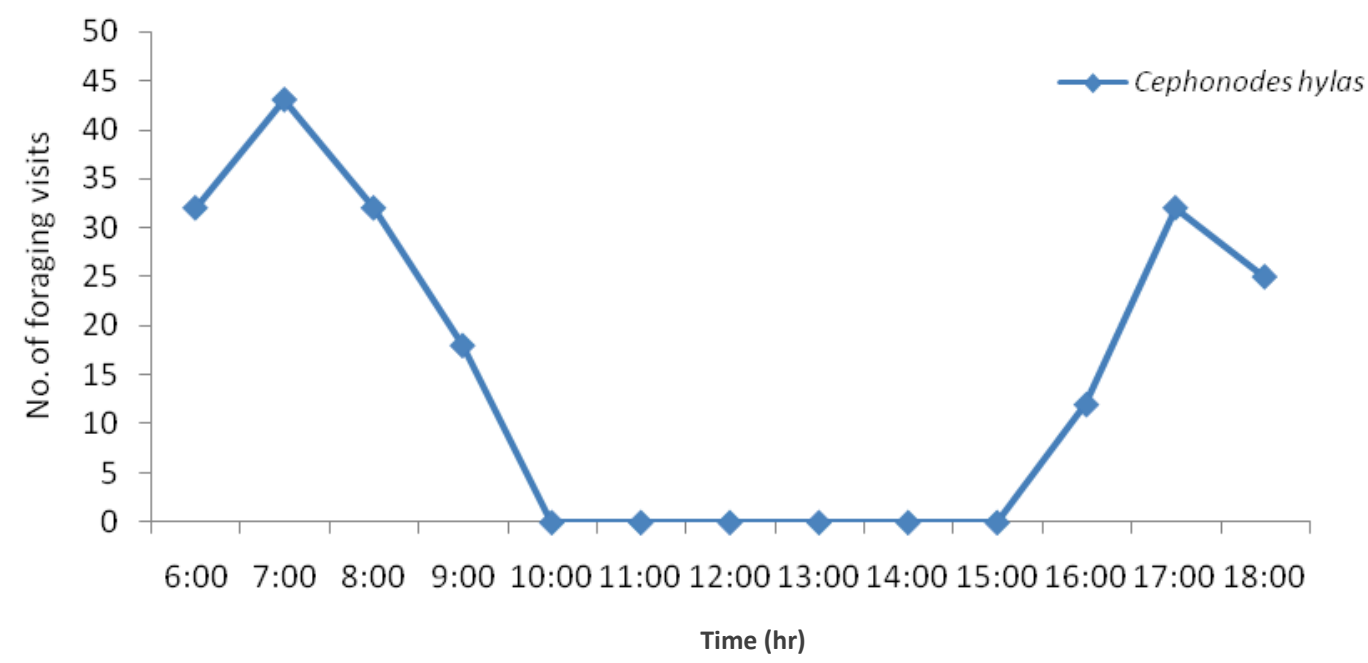

Figure 7. Hourly foraging activity of hawk moth on Syzygium alternifolium

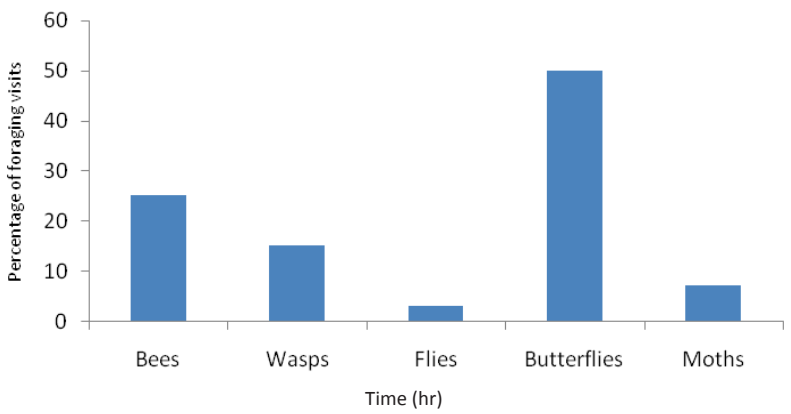

Figure 8. Percentage of foraging visits of different categories of insects on Syzygium alternifolium

vegetative development and fruiting. Lavee (2007) suggested that flowering and subsequent fruit bearing could be a built-in character and over all controlled by an interaction between vegetative growth and fruit load. Such an expression involves a wide range of changes in activation and repression of endogenous metabolic pathways. A continuous and complex interaction between the ambient temperature, humidity and other environmental factors is involved in both the vegetative and reproductive development. Sanewski (2010) stated that in most tree species, adequate starch levels are required for the production of flowers, particularly mass-flowering species, like most of the Syzygium. Trees with insufficient starch levels may not flower heavily in that year and hence, gradually move into an alternate bearing pattern. Adequate starch reserves are a prerequisite for flowering while environmental factors are usually the trigger. The variation in flowering intensity in the mass blooming $S$. alternifolium could be attributable to starch levels available at the time of flowering season.
Several studies have documented the influence of rainfall or water levels on the flowering intensity in mass blooming Syzygium species. In southern Taiwan, Liao \& Lin (2001) reported that S. samarangense exhibited early mass flowering in summer after flooding for about 40 days at the site. Falcao et al. (2002) reported that $S$. malaccensis flowers twice in a single year, the first spell in wet season and the second spell in dry season in Brazil (Falcao et al. 2002). Tarai \& Kundu (2008) noted that $S$. aquem flowers twice in a single year in India. Sanewski (2010) observed that S. luehmannii flowered massively in the first spell and showed minor flowering in the second spell after unseasonal heavy rainfall in spring in southeast Queensland, Australia and attributed such a flowering response to the prevailing temperature and water availability (Sanewski 2010). Law et al. (2000) reported that high rainfall in summer-autumn period resulted in heavy flowering in spring for most of the Myrtaceae members. Keatley et al. (2002) reported a significant relationship between temperature and rainfall and flowering in eucalypts over 23 years. Therefore, water, temperature and soil nutrient status appear to influence and regulate the flowering event collectively in S. alternifolium.

The studied species of Syzygium for their breeding systems indicate that both self-compatible and selfincompatible species exist in this genus but selfcompatible species are most common (Sanewski 2010). S. tierneyanum and S. nervosum in northern Australia (Hopper 1980; Shapcott 1998), S. cuminii in India (Reddi \& Rangaiah 1999-2000), S. rubicundum in Sri Lanka (Stacey 2001), S. lineatum in Indonesia (Lack \& Kevan 1984), and S. samarangense, S. jambos, S. megacarpum, 
and S. formosum in Thailand (Chantaranothai \& Parnell 1994) are self-compatible. S. syzygiodes is strongly selfincompatible in Sulawesi (Williams \& Adam 2010) and S. cormiflorum in Australia is basically a xenogamous species (Crome \& Irvine 1986). The present study shows that $S$. alternifolium is self-incompatible and an obligate out-crosser. Khan et al. (1999) also mentioned that it is an out-breeder and routinely propagated by seed. Floral overproduction through mass flowering pattern and production of floral rewards in all flowers through hermaphroditic sexual system appear to be evolved characters for the attraction of more pollinators and for the function of obligate out-crossing breeding system. However, the success of this breeding system depends on the cross-pollination rate which in turn is linked to the foraging efficiency and the frequency of inter-plant foraging visits by effective pollinators. Although the plant is characteristically a mass bloomer, all the individuals do not flower consecutively and even those flowering in consecutive years do not show mass blooming. Such a flowering pattern affects the out-crossing rate as well as fruiting rate and hence, is a limitation for the success of sexual reproduction in S. alternifolium. Nevertheless, the mass blooming years facilitate higher fruit set and provide a 'reproductive assurance' against moderate to sparse flowering years and losses due to bud and flower infestations which are evidenced in the present study. The bud infestation in S. alternifolium is because of breeding by a moth species. The adult moth deposits its eggs in young flower buds and the developing larvae consume the entire bud over a period of approximately one week. Such a bud infestation by a moth, Polyhymno sp. has been reported in $S$. mamillatum (Kaiser et al. 2008).

Myrtaceae members, in general, do not have specialized pollination systems and attract a wide range of vertebrate and invertebrate floral visitors (Eldridge 1970; Carpenter 1976; Hopper 1980; Hopper \& Moran 1981). Williams \& Adam (2010) documented the pollination biology aspects of Syzygium tierneyanum, S. sayeri, S. floribundum and $S$. cormiflorum. $S$. tierneyanum is visited by 45 species of nectar feeding animals; honeyeaters and hawk moths are considered as most important pollinators due to their abundance and foraging behavior despite the honeybees being the prolific visitors. Blossum bats and honeyeaters contribute about half of the pollination rate and the rest is contributed mainly by butterflies, flies, thrips and wasps in S. sayeri. The mass-flowering $S$. floribundum is pollinated by a guild of insects but bats do not visit its flowers although they occur in the area. In $S$. cormiflorum, birds, insects and particularly blossom bats are effective pollinators; the last together with hawk moths constitute a greatest percentage of successful pollination (Crome \& Irvine 1986; Williams \& Adam 2010). S. paniculatum with generalized pollination strategy is visited by a variety of insects (Payne 1991, 1997). In Sulawesi, S. syzygiodes and occurring in the lowland rain forest is entomophilous and pollinated by a guild of short-tongued unspecialized insects. In Samoa, S. inophylloides and S. samarangense are regularly foraged by birds (Cox et al. 1992). Empirical studies on the pollination of Syzygium species here are absent but observers have suggested that bats are important pollinators of these species (Wiles \& Fujita 1992; Trail 1994; Banack 1996). In American Samoa, S. dealatum is primarily pollinated by the invertebrates and one small vertebrate. Birds and bats do not visit its flowers although they are present at the study site. Further, it is also considered to be anemophilous due to its location on a highly exposed rocky point characterized by high wind speeds. Insects are relatively more important pollinators of $S$. effusum and birds and bats are likely most important pollinators of S. neurocalyx (Webb \& Solek 1996). In East Java, S. pycnanthum is reported to be visited by a guild of insects by Mudiana \& Ariyanti (2010). S. mamillatum is pollinated by generalist bird species in Mauritius (Kaiser et al. 2008). S. mundagam in the wet evergreen forest of Western Ghats of India is pollinated exclusively by bats (Ganesh 1996). In southern India, $S$. cuminii with chiropterophilous pollination syndrome is in reality entomophilous and effected by twenty-four species of insects consisting of nocturnal, crepuscular and diurnal ones (Reddi \& Rangaiah 1999-2000). But, these authors stated that entomophily is ineffective and as a result it has evolved certain floral traits that facilitate effective anemophily.

In S. alternifolium, the floral characters such as the flower-opening during dusk hours, commencement of stigma receptivity during late evening and weak nectar by sugar concentration are adaptations for chiropterophily (Faegri \& van der Pijl 1979; Wyatt 1983; Crome \& Irvine 1986). But, bats never visited the flowers though they are common in the region. The diurnal Hawk Moth Cephonodes hylas is the only species that visits the flowers during dusk hours. It is a swift flier, gathers nectar quickly from each flower and moves fast between inflorescences and conspecific plants. It strikes the dehisced stamens and stigma while collecting nectar and contributes primarily to cross-pollination since the stigma is not receptive then in fresh flowers but receptive in two-day old flowers. The same moth is the 
first visitor to the flowers during early morning hours and contributes to cross-pollination in both one-day and twoday old flowers. African Fat-tailed Gecko Hemitheconyx caudicinctus is a nectar-feeder after sunset and until late evening. It does not contribute to cross-pollination since it remains on the same plant collecting nectar from fresh or old flowers. The floral characters such as intense flowering, sweet-scented and actinomorphic flowers, shaving-brush type stamens and copious nectar are adaptive for generalist flower visitors. In line with this, bees, wasps and butterflies are found to be prolific foragers during daytime up to noon-time. The observed foraging behaviours of these insects indicate that Apis dorsata and Amegilla sp. among bees and all visiting wasps are important in effecting cross-pollination due to their frequent foraging flights between conspecific flowering individuals while all others play little role in promoting cross-pollination. All these insects exhibit flower constancy during the entire length of flowering period of S. alternifolium since the flowers are important pollen and nectar sources. The nectar is rich in protein content, sucrose sugar and also a source of six essential and nine non-essential amino acids for insects. Both invertebrate (insects) and vertebrate (gecko) foragers are highly benefitted during the flowering season of $S$. alternifolium, when food resources are scarce due to the absence of flowering in most of the co-occurring plants in the study region. However, S. alternifolium is not an assured food source for them every year due to great variation in the intensity of flowering annually. During the years of low intensity of flowering, they shift to Shorea roxburghii and S. tumbuggaia which flower almost at the same time. But, the flowers of these two species are not preferred when mass flowering occurs in S. alternifolium.

In S. alternifolium, the pollen is liberated into the ambient environment with two peak concentrations, one at 19:00hr and the second at 09:00hr. The pollen concentration gradually decreases with the distance from the plant. The triangular and tricolporate nonsticky pollen grains that fall in the size range of $12-58$ $\mu \mathrm{m}$ are suited for anemophily (Erdtman 1952; Srivastava 1982). The pollen grains of $S$. alternifolium also have the same characteristics and their size is $16.6 \mu \mathrm{m}$. These characteristics and the pollen release into the ambient environment conform to the occurrence of anemophily. The location of the plant on the exposed rocky area and the occurrence of high wind speed are additional advantages for effective anemophily as in case of $S$. dealatum in American Samoa (Webb \& Solek 1996). Therefore, S. alternifolium with generalist pollination system is adapted to both entomophily and anemophily, the occurrence of which is referred to as ambophily, sensu Yamasaki \& Sakai (2013).

Webb \& Solek (1996) stated that the generalist pollination system would increase the probability of successful establishment by Syzygium species in novel environments, including islands. Their statement appears to be based on self-compatible species like $S$. cormiflorum which breeds through geitonogamy and hence could significantly contribute to the wide distribution of the species. In the present study, $S$. alternifolium with generalist pollination system cannot establish in isolated or novel environments in the absence of other conspecific individuals nearby or in the surroundings due to self-incompatible and obligate outcrossing breeding system. Khan et al. (1999) reported that vegetative propagation is also not a successful mode in S. alternifolium. These could be important limitations for the restricted distribution of the species only to this part of India.

In S. alternifolium, the fruit set and seed set rates are the same due to the production of 1-seeded fruits. With generalist pollination system and ambophily, the plant is able to set fruit at $11 \%$ despite the presence of selfincompatibility, inefficient insect pollination, soil water stress and nutrient deficiency. Further, highly significant bud infestation by a moth, flower predation by the beetle, Popillia impressipyga and common occurrence of mounds formed of buds and flowers collectively show significant negative impact on the success of sexual reproduction. Therefore, both intrinsic and external factors regulate the production of ultimate fruit set.

Boyer (1982) stated that the most growing conditions enable many plant species to initiate sufficient numbers of ovules to maximize reproduction. But most plants do not experience optimal growth conditions and hence they inevitably abort some of these ovules. Lee \& Bazzaz (1986) reported that the nutritional demand of reproduction frequently exceeds the carbon and nitrogen resources allocated to the ovule under environmental stress. Consequently, the number of ovules initiated often exceeds the capacity of the gynoecium or, by extension, the plant to provide adequate nutrition for them all. Westgate \& Boyer (1985) reported that the rate of photosynthesis dramatically drops in maize following water stress while Schussler \& Westgate (1995) as a follow up study reported that this dramatic drop in photosynthesis results in reduced sugar transport into the embryo sac and in effect, it limits resources for seed development. These authors also noted that in healthy plants, manual removal of some developing ovules 
decreases the overall rate of abortion by providing more photosynthate for surviving ovules. El-Keblawy \& Lovell-Doust (1999) in a subsequent study on cucurbits reported that the total number of ovules maturing into seeds remained steady while the rate of ovule abortion declined when a portion of the ovules were surgically removed from the ovary. On the contrary, $S$. alternifolium under water stress and nutrient-deficient environment during dry season produces the same number of ovules per ovary but only one ovule forms the seed. It indicates that the plant does not have any regulatory mechanism to prevent overproduction of ovules to save energy resources for more seed output. Lughada \& Proenca (1996) reported that in Myrtaceae species, the ovary usually contains more embryos than will form seed. Arathi et al. (1996) and Krishnamurthy et al. (1997) have studied ovule abortion in S. cuminii and related this event to an inhibition of resource uptake by the sub-ordinate seeds. They also substantiated this observation by experimental work in which the extracts from the dominant seeds, containing predominately indole compounds inhibited resource uptake by the subordinate seeds and hence the plant usually develops only 1 of 30 ovules to maturity. Such a situation can be expected in its allied species, S. alternifolium in which also only 1 out of 21-38 ovules forms the seed.

InSyzygium genus, apomixis occurs and it is considered to be linked to polyembryony (Chantaranothai \& Parnell 1994; Lughadha \& Proenca 1996). S. cuminii (Arathi et al. 1996; Krishnamurthy et al. 1997; Kader et al. 2000), S. javanicum (Ikeda 1979), and S. jambolana (Ladhar \& Gill 1991) and S. alternifolium (Khan et al. 1995) are polyembryonic. The present study indicates that $S$. alternifolium is neither apomictic nor polyembryonic; the seed characteristically produces a single seedling.

Maturation, dispersal and germination of tree seeds in the seasonally dry tropical forest ecosystem are synchronized to a considerable extent to seasons (Frankie et al. 1974; Garwood 1982). Dry fruits more frequently ripen and disperse seeds during the dry season, while fleshy and pulpy fruits ripen and disperse seeds during the rainy season (Roth 1987). A majority of fleshy and pulpy fruits produce seeds that take a long time to germinate, possibly because of their dependence on frugivores for dispersal. These are seeds mostly with hard, mechanically resistant coats that protect the embryo from damage during chewing or enzymatic action while passing through the gut. Seeds of some species of this category take several years to germinate (Troup 1921) and length of dormancy could be a secondary effect of a defense mechanism.
Other fruits that depend on slow decomposition or insect action for release of seeds take a long time to germinate. These requirements may have led to selection for delayed germination. Thus, it follows that, subsequent to maturation, three conditions determine the fate of seeds: dispersal at the appropriate season favourable for germination, germination at favourable times by those remaining dormant, until conditions become conducive for germination, or germination after they are carried to a habitat favourable for germination. Corlett (1996) stated that colourful displays of ripe fruit likely evolved in order to attract avian dispersal agents. Frugivorous birds, thus, serve as selective agents of plants by favoring those species whose seeds could disperse to potential safe sites. The subsequent seed dispersal pattern not only determines the potential area of plant recruitment, but also serves as a template for subsequent processes, such as predation, competition and mating (Nathan \& Muller-Landau 2000). The fruits of red, brown, deep brown color with pulp as a reward exhibit animal dispersal mode (Du et al. 2009). On the contrary, S. alternifolium exhibits colourful displays of unripe and ripe fruits but they are never used by avians. The fallen fruits are mostly collected by locals due to their edible nature and there was no fruit or seed predation by animals. But, an earlier report by Mohan \& Lakshmi (2000) stated that the fruits are relished by Wild Boar, Sloth Bear and herbivores such as Sambar. Nevertheless, only the leftover fruits or seeds have the chance for germination and subsequent formation of seedlings under optimal growth conditions. Khan et al. (1999) reported that seeds of S. alternifolium cannot be stored for long periods due to short viability and insect attack. The present study also shows that most of the seeds of S. alternifolium are healthy, viable and germinate immediately if favourable soil water and nutrient conditions exist; high germination rate could be because of quality seed resulting from cross-pollination. Further, insect attack on the fruits or seeds was not observed but the pulpy part gradually decomposed exposing the seed during rainy season. Since the seed viability is short, its viability span lasts only until the end of rainy season and hence it does not have several opportunities for germination thereafter. Even when germinated, the seedlings experience mortality due to erratic rainfall or interval of drought within the rainy season (Troup 1921). Therefore, rainy season is the prime determinant of seed germination and seedling establishment in S. alternifolium. This finding is in line with the generalization made by Angevine \& Chabot (1979) that in most tropical forests of India, a 3-month 
monsoon period is the prime determinant of all biological processes, including seed germination, seedling establishment and plant growth and development. Germination responses during monsoon period are suggestive of the occurrence of drought avoidance syndrome in majority of tree species and most other plants in these tropical forests.

\section{REFERENCES}

Angevine, M.W. \& B.F. Chabot (1979). Seed germination syndromes in higher plants, pp. 188-206. In: Solbrig, O.T., S. Jain, G.B. Johnson \& P.H. Raven (eds.). Topics in plant population biology. Columbia University Press, New York.

Anonymous (1956). The Wealth of India. Raw Materials - Vol. X. Publication and Information Directorate, CSIR, New Delhi, India, 356pp.

Arathi, H.S., K.N. Ganeshaiah, R.U. Shaanker \& S.G. Hegde (1996) Factors affecting embryo abortion in Syzygium cumini (L.) Skeels (Myrtaceae). International Journal of Plant Sciences 157: 49-52.

Bajpai, A., A.K. Singh \& H. Ravishankar (2012). Reproductive phenology, flower biology and pollination in Jamun (Syzygium cuminii L.). Indian Journal of Horticulture 69(3): 416-419.

Baker, H.G. \& I. Baker (1973). Some anthecological aspects of the evolution of nectar producing flowers particularly amino acid production in nectar, pp. 243-281. In: Heywood, V.H. (ed.). Taxonomy and Ecology. Academic Press, London.

Bakshu, L.M. (2002). Ethnomedicobotanical and phytochemical evaluation of certain rare, endemic and endangered medicinal plants from Eastern Ghats, Andhra Pradesh, India. PhD Thesis. S.K. University, Anantapur.

Banack, S.A. (1996). Flying foxes, genus Pteropus, in the Samoan Islands: interactions with forest communities. PhD Dissertation, University of California, Berkeley, CA.

Bhattacharya, K., M.R. Majumdar \& S.G. Bhattacharya (2006). A Textbook of Palynology (Basic and Applied). New Central Book Agency (P) Ltd., Kolkata, 352pp.

Boyer, J.S. (1982). Plant productivity and the environment. Science 218(4571): 443-448; http://dx.doi.org/10.1126/ science.218.4571.443

Carpenter, F.L. (1976). Plant-pollinator interactions in Hawaii: pollination energetic of Metrosideras collina (Myrtaceae). Ecology 57: 1125-1144.

Chantaranothai, P. \& J.A.N. Parnell (1994). The breeding biology of some Thai Syzygium species. Tropical Ecology 35(2): 199-208.

Chitra, V. (1983). Elaeocarpaceae, pp. 46-47. In: Nair, N.C. \& A.H. Henry (eds.). Flora of Tamil Nadu. 1. Botanical Survey of India, Coimbatore, $184 \mathrm{pp}$.

Corlett, R.T. (1996). Characteristics of vertebrate-dispersed fruits in Hong Kong. Journal of Tropical Ecology 12(6): 819-833; http:// dx.doi.org/10.1017/S0266467400010075

Cox, P.A., T. Elmqvist, E.D. Pierson \& W.E. Rainey (1992). Flying foxes as pollinators and seed dispersers in Pacific island ecosystems. Biological Report 90: 18-23.

Crome, F.H.J. \& A.K. Irvine (1986). "Two Bob Each Way": The pollination and Breeding system of the Australian rain forest tree Syzygium cormiflorum (Myrtaceae). Biotropica 18: 115-125.

Dafni, A., P.G. Kevan \& B.C. Husband (2005). Practical Pollination Biology. Enviroquest Ltd., Canada, 583pp.

Du, Y., X. Mi., X. Liu., L. Chen \& K. Ma (2009). Seed dispersal phenology and dispersal syndromes in a subtropical broad-leaved forest of China. Forest Ecology and Management 258(7): 1147-1152; http:// dx.doi.org/10.1016/j.foreco.2009.06.004

Eldridge, K.G. (1970). Breeding system of Eucalyptus regnans. Proc.
IUFRO Sect. 22 Meeting, Varparanta, Finland. Vol. 1.

El-Keblawy, A. \& J. Lovell-Doust (1999). Maternal effects in the progeny generation in Zucchini, Cucurbita pepo (Cucurbitaceae). International Journal of Plant Sciences 160: 331-339.

Erdtman, G. (1952). Pollen Morphology and Plant Taxonomy: Angiosperms. Almqvist and Wiksell, Stockholm, 539pp.

Faegri, K. \& L. van der Pijl (1979). The Principles of Pollination Ecology. Pergamon Press, Oxford, 244pp.

Falcao, M.A., N.D. Paralupp \& C.R. Clemend (2002). Fenologia e produtividade do jambo (Syzygium malaccensis) na Amazonia Central. Acta Amazonica 32: 3-8.

Frankie, G.W., H.G. Baker \& P.A. Opler (1974). Comparative phenological studies of trees in tropical wet and dry forests in the lowlands of Costa Rica. Journal of Ecology 62: 881-913.

Gamble J.S. (1957). Flora of the Presidency of Madras. Botanical Survey of India, Calcutta, 340pp.

Ganesh, T. (1996). Fruiting patterns among canopy trees and fruit use by vertebrates in a wet evergreen forest of Western Ghats, India. PhD Dissertation, Pondicherry University, Pondicherry, India.

Garwood, N.C. (1982). Seasonal rhythm of seed germination in a semi-deciduous tropical forest, pp. 173-185. In: Leigh, E.G., A.S. Rand \& D.M. Windsor (eds.). The ecology of a tropical forest: seasonal rhythms and long-term changes. Smithosonian Institution Press, Washington DC.

Guptha, M.B., P.V.C. Rao \& D.S. Reddy (2012). A Preliminary observation on butterflies of Seshachalam Biosphere Reserve, Eastern Ghats, Andhra Pradesh, India. World Journal of Zoology 7: 83-89.

Hopper, S.D. (1980). Pollination of the rain forest tree Syzygium tierneyanum (Myrtaceae) at Kuranda, northern Australia. Australian Journal of Botany 28: 223-237.

Hopper, S.D. \& G.F. Moran (1981). Bird pollination and the mating system of Eucalyptus stolaei. Australian Journal of Botany 29: 625638.

Ikeda, M. (1979). Studies on fruit characteristics and seedless fruit formation of Senarang Rose Apple, Syzygium javanicum Merr. and Perry in South Vietnam. Mem. Fac. Arg. Kagoshima University 15: 55-62.

Kader, S.A., K.R. Bindu \& K.C. Chacko (2000). Polyembryony in Syzygium cumini (L.) Skeels and in Vateria indica L. Indian Forester 126: 1353-1356.

Kaiser, C., D.M. Hansen \& C.B. Muller (2008). Habitat structure affects reproductive success of the rare endemic tree Syzygium mamillatum (Myrtaceae) in restored and unrestored sites in Mauritius. Biotropica 40(1): 86-94; http://dx.doi.org/10.1111/ j.1744-7429.2007.00345.x

Keatley, M.R., T.D. Fletcher, I.L. Hudson \& P.K. Ades (2002). Phenological studies in Australia: potential application in historical and future climate analysis. International Journal of Climatology 22(14): 1769-1780; http://dx.doi.org/10.1002/joc.822

Khan, P.S., G. Sudarsanam \& K.R. Rao (1995). Polyembryony and in vitro seed culture in Syzygium alternifolium (Wight) Walp. Journal of Phytological Research 8: 119-122.

Khan, P.S.S.V., J.F. Hausman \& K.R. Rao (1999). Clonal multiplication of Syzygium alternifolium (Wieght.) Walp. Through mature nodal segments. Silvae Genetica 48: 45-50.

Krishnamurthy, K.S., R.U. Shaanker \& K.N. Ganeshaiah (1997). Seed abortion in an animal dispersed species, Syzygium cumini (L.) Skeels (Myrtaceae): the chemical basis. Current Science 73: 869-873.

Lack, A.J. \& P.G. Kevan (1984). On the reproductive biology of a canopy tree, Syzygium syzygioides (Myrtaceae), in a rain forest in Sulawesi, Indonesia. Biotropica 16(1): 31-36.

Ladhar, S.S. \& B.S. Gill (1991). Growth behavior of intraspecific cytotypes of Eugenia jambolana Lamk. Indian Forester 117: 652654.

Lavee, S. (2007). Biennial bearing on Olive (Olea europaea). Annales Series Historia Naturalis 17: 101-112.

Law, B., L. Mackowski, L. Schoer \& T. Tweedie (2000). Flowering phenology of myrtaceous trees and their relation to climatic, 
environmental and disturbance variables in northern New South Wales. Australian Ecology 25(2): 160-178; http://dx.doi. org/10.1046/j.1442-9993.2000.01009.x

Lee, T.D. \& F.A. Bazzaz (1986). Maternal regulation of fecundity: nonrandom ovule abortion of Cassia fasciculata Michx. Oecologia 68: 459-465.

Liao, C.T. \& C.H. Lin (2001). Physiological adaptation of crop plants to flooding stress. Proceedings of the National Science Council 25: 148-157.

Lughadha, E.N. \& C. Proenca (1996). A survey of the reproductive biology of the Myrtoideae (Myrtaceae). Annals of the Missour Botanical Garden 83: 480-503.

Misra, R.S. \& P.N. Bajpai (1984). Studies on pollination, fruit set, and fruit development in Jamun (Syzygium cuminii Skeel). Progressive Horticulture 16: 1-5.

Mohan, B.A. \& B.B. Lakshmi (2000). Brief note on Syzygium alternifolium (Wight) Walp., an endemic plant species found in $\mathrm{Sr}$ Venkateswara Wildlife Sanctuary of Andhra Pradesh, with specia reference to its fruiting. Zoos' Print Journal 15(2): 210; http://dx.doi. org/10.11609/JoTT.ZPJ.15.2.210

Mohan, A.R., K.V.S.R.G. Prasad \& J.A.R.P. Sharma (2010). Evolution of anti-inflammatory activity of aqueous extracts of Syzygium alternifolium. International Journal of Pharmaceutical Sciences 2: 865-870.

Mudiana, D. \& E.E. Ariyanti (2010). Flower and fruit development of Syzygium pycnanthum Merr. \& L.M. Perry. Biodiversitas 11: 124128.

Nagaraju, N. \& K.N. Rao (1990). A survey of plant crude drugs of Rayalaseema, Andhra Pradesh, India. Journal of Ethnopharmacology 29: 137-158.

Nathan, R. \& H.C. Muller-Landau (2000). Spatial patterns of seed dispersal, their determinants and consequences for recruitment. Trends in Ecology and Evolution 15: 278-285.

Payne, R. (1991). New findings of the rare tree Syzygium paniculatum (Myrtaceae) in the Wyong area, New South Wales. Cunninghamia 2: 495-498.

Payne, R. (1997). The Distribution and Reproductive Ecology of Syzygium paniculatum and Syzygium austral (Myrtaceae) in the Gosford-Wyong Region. MSc Thesis. University of New England, Armidale, New South Wales.

Perkins, W.A. (1957). The Rotorod Sampler. $2^{\text {nd }}$ Semi-annual Report, Aerosol Laboratory, Department of Chemistry and Chemical Engineering, Stanford University, CML., 186: 1-66.

Rao, B.K. \& C.H.A. Rao (2001). Hypoglycemic and anti-hyperglycemic activity of Syzygium alternifolium, seed extracts in normal and diabetic rats. PhD Thesis, Sri Venkateswara University, Tirupati.

Reddi, E.U.B. \& K. Rangaiah (1999-2000). Breeding systems and pollinating agents of the Indian Blackberry, Syzygium cuminii (L.) Skeels (Myrtaceae). Journal of Palynology 35-36: 117-128.

Reddy, K.R., G. Sudarsanam \& P.G. Rao (1989). Plant crude drugs of Chittoor district, Andhra Pradesh, India. International Journal of Crude Drug Research 27: 41-54.

Reddy, K.N. \& C.S. Reddy (2008). First Red List of medicinal plants of Andhra Pradesh, India - conservation assessment and management planning. Ethnobotanical Leaflets 12: 103-107.

Reddy, C.S., K.N. Reddy, C. Pattanaik \& V.S. Raju (2006). Ethnobotanical observations on some endemic plants of Eastern Ghats, India. Ethnobotanical leaflets 10: 82-91.
Roth, I. (1987). The Dispersal of Plants Throughout The World. Reeve and Co., Ashford, 744pp.

Saldanha, C.J. (1996). Flora of Karnataka - Volume II. Oxford and IBH Publishing Co., New Delhi, 535pp.

Sanewski, G.M. (2010). Understanding the cropping behavior of Riberry (Syzygium luehmannii). RIRDC Publication No. 10/194, Union Offset Printing, Canberra.

Schussler, J.R. \& M.E. Westgate (1995). Assimilate flux determines kernel set at low water potential in maize. Crop Science 35: 10741080; http://dx.doi.org/10.2135/cropsci1995.0011183X003500040 $026 \mathrm{x}$

Shapcott, A. (1998). Vagile but inbred-patterns of inbreeding and the genetic structure within populations of the monsoon rain forest tree Syzygium nervosum (Myrtaceae) in northern Australia. Journal of Tropical Ecology 14: 595-614; http://dx.doi.org/10.1017/ S026646749800042X

Srivastava, D. (1982). Studies in the pollen biology of certain cultivated Malvaceae. Advances in Pollen-Spore Research 9: 82-91.

Stacey, E.A. (2001). Cross-fertility in two tropical tree species: evidence of inbreeding depression within population and genetic divergence among populations. American Journal of Botany 88: 1041-1051.

Tarai, R.K. \& S. Kundu (2008). Flowering behavior of eight minor fruit crops in the new alluvial zone of West Bengal. Journal of Interacademicia 12: 292-296.

Trail, P.W. (1994). The phenology of rainforest plants in Tutuila, American Samoa. Unpublished Manuscript. Department of Marine and Wildlife Resources, American Samoa Government.

Troncoso, A., J.L. Garcia \& S. Lavee (2006). Evaluation of the present information on the mechanisms leading to flower bud induction, evocation and differentiation. $5^{\text {th }}$ International Congress on Olive growing. Turkey Acta Horticulture 744: 377-380.

Troup, R.S. (1921). Silviculture of Indian Trees. Clarendon Press, Oxford, 1195pp.

Verdcourt, B. (2001). Myrtaceae. In: Beentje, H.J. \& A.A. Balkema (eds.). Flora of Tropical East Africa. Rotterdam, Netherlands, 89pp.

Webb, E.L. \& C. Solek (1996). Notes on the pollination of Syzygium dealatum (Burkill) A.C. Smith (Myrtaceae) in American Samoa. Pago Pago, DMWR: 1-11.

Westgate, M.E. \& J.S. Boyer (1985). Carbohydrate reserves and reproductive development at low leaf water potentials. Crop Science 25: 762-769; http://dx.doi.org/10.2135/cropsci1985.0011 183X002500050009x

Wiles, G.J. \& M.S. Fujita (1992). Food plants and economic importance of flying foxes in Pacific islands. Biological Report 90: 24-35.

Williams, G. \& P. Adam (2010). The Flowering of Australia's Rainforests. CSIRO Publishing, Melbourne, 200pp.

Wrigley, J.W. \& M.A. Fagg (2003). Australian Native Plants: Cultivation, use in Landscaping and Propagation. Reed new Holland, Australia, 696pp.

Wyatt, R. (1983). Pollinator-plant interactions and the evolution of breeding system, pp. 51-95. In: Real, L. (ed.). Pollination Biology. Academic Press, New York.

Yamasaki, E. \& S. Shoko (2013). Wind and insect pollination (ambophily) of Mallotus spp. (Euphorbiaceae) in tropical and temperate forests. Australian Journal of Botany 61: 60-66; http:// dx.doi.org/10.1071/BT12202. 